Nevada

Environmental

Restoration

Project

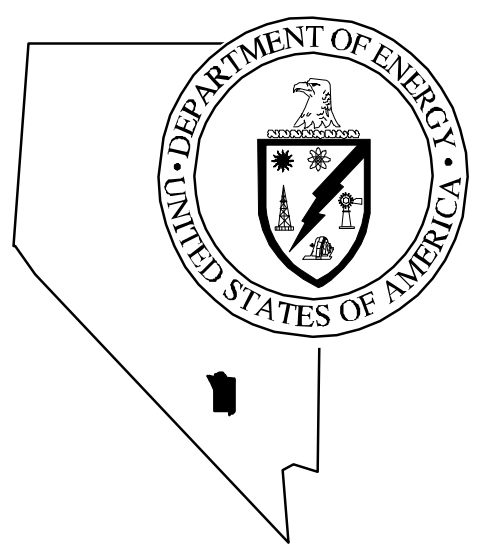

Corrective Action Investigation Plan

for Corrective Action Unit 232:

Area 25 Sewage Lagoons

$\mathrm{N}$ evada Test $\mathrm{Site}, \mathrm{N}$ evada

Controlled Copy $\mathrm{N}$ O.: - -

Revision N 0.: 0

M ay 1999

Approved for public release; further distribution is authorized.

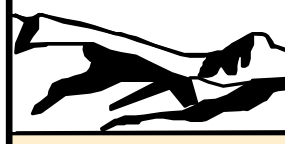

Environm ental Restoration

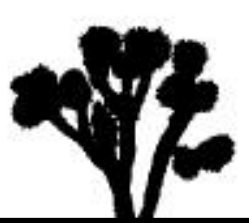

Division 
Available to the public from -
U.S. Department of Commerce
National Technical Information Service
5285 Port Royal Road
Springfield, VA 22161
(703) 487-4650

Available electronically at http://www.doe.gov/bridge. Available to U.S. Department of Energy and its contractors in paper from -

\section{U.S. Department of Energy}

Office of Scientific and Technical Information

P.O. Box 62

Oak Ridge, TN 37831-0062

(423) 576-8401

Reference herein to any specific commercial product, process, or service by trade name, trademark, manufacturer, or otherwise, does not necessarily constitute or imply its endorsement, recommendation, or favoring by the United States Government or any agency thereof or its contractors or subcontractors. 


\title{
CORRECTIVE ACTION INVESTIGATION PLAN FOR CORRECTIVE ACTION UNIT 232: AREA 25 SEWAGE LAGOONS NEVADA TEST SITE, NEVADA
}

\author{
DOE Nevada Operations Office \\ Las Vegas, Nevada
}

Controlled Copy No.:

Revision No.: 0

May 1999

Approved for public release; further distribution is authorized. 


\section{CORRECTIVE ACTION INVESTIGATION PLAN \\ FOR CORRECTIVE ACTION UNIT 232: \\ AREA 25 SEWAGE LAGOONS \\ NEVADA TEST SITE, NEVADA}

Approved by: $\frac{\text { Signature Approved }}{\text { Janet Appenzeller-Wing, Project Manager }}$ Date: $\quad$ 4/29/99

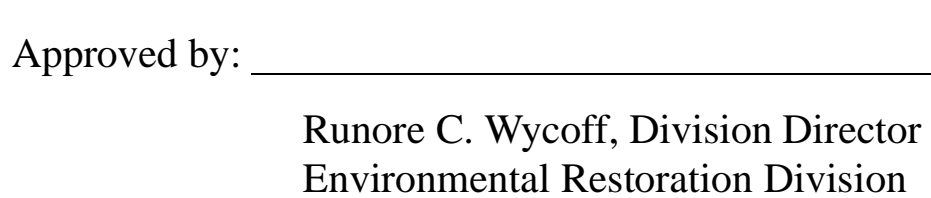

Date: 4/29/99 


\section{Table of Contents}

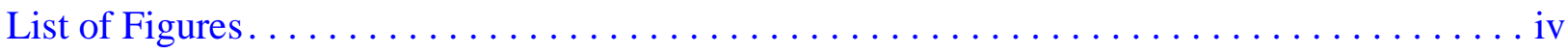

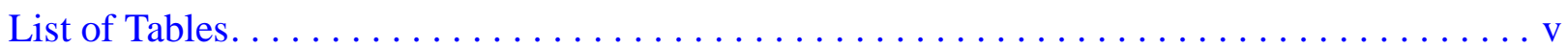

List of Acronyms and Abbreviations $\ldots \ldots \ldots \ldots \ldots \ldots \ldots \ldots \ldots \ldots \ldots \ldots \ldots \ldots \ldots$

Executive Summary . . . . . . . . . . . . . . . . . . . . . . . . . . ES-1

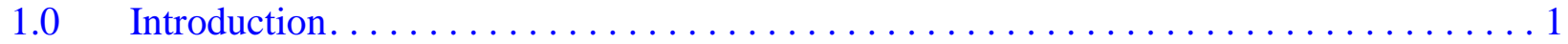

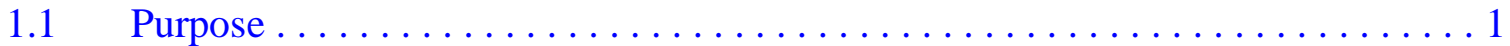

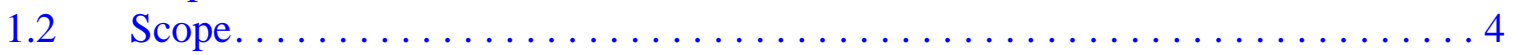

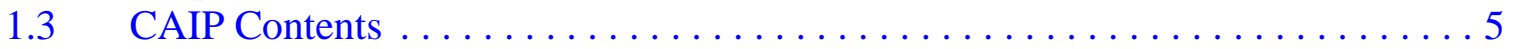

$2.0 \quad$ Facility Description. . . . . . . . . . . . . $6 \ldots \ldots \ldots \ldots \ldots \ldots \ldots \ldots$

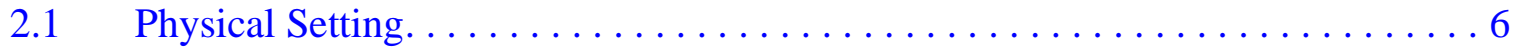

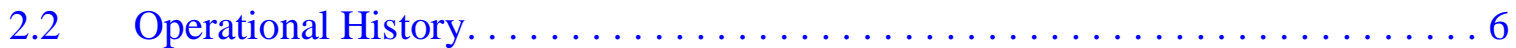

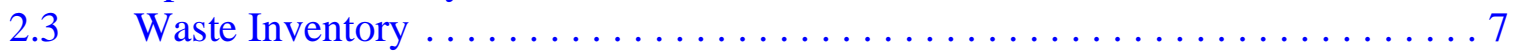

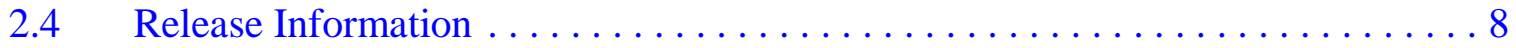

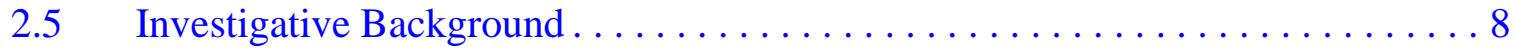

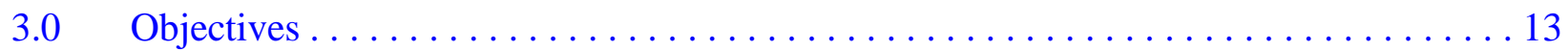

$3.1 \quad$ Conceptual Site Model . . . . . . . . . . . . . . . . . . . 13

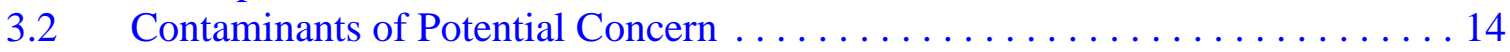

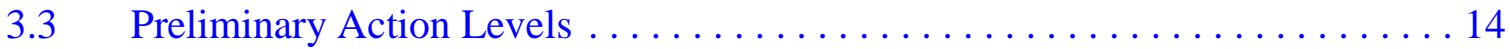

3.3.1 Field Screening Levels . . . . . . . . . . . . . . . . . . . . . . . 14

3.3.2 Chemical Preliminary Action Levels . . . . . . . . . . . . . . . . 15

3.3.3 Radiological Preliminary Action Levels. . . . . . . . . . . . . . . . . 15

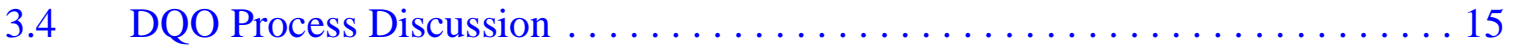

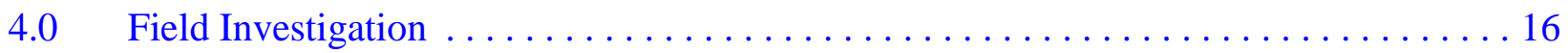

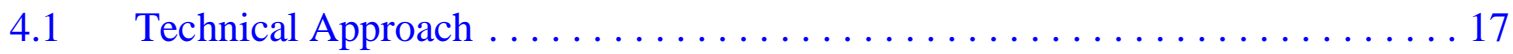

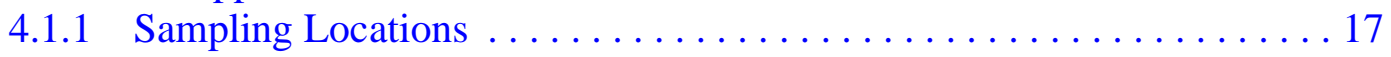

4.1 .2 Sampling Criteria . . . . . . . . . . . . . . . . . . . . . 19

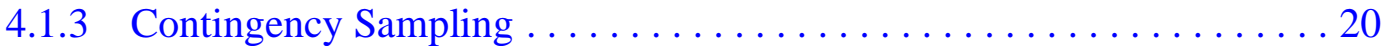

4.1 .4 Field Screening . . . . . . . . . . . . . . . . . . . . 20

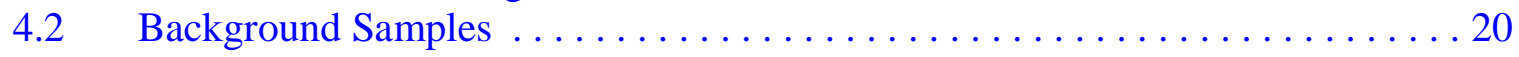

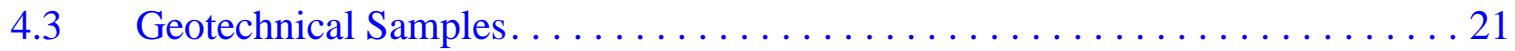

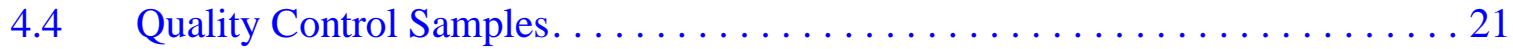

4.5 Sample Collection Procedures . . . . . . . . . . . . . . . . . . . . . 22

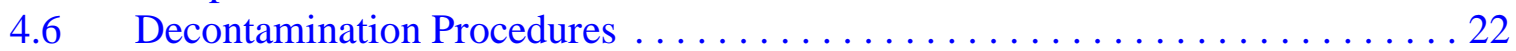

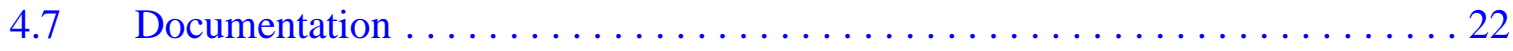




\section{Table of Contents (Continued)}

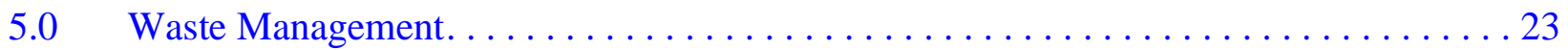

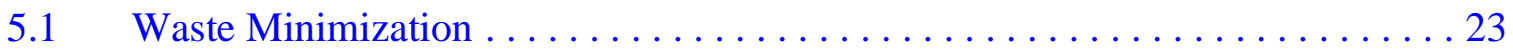

$5.2 \quad$ Potential Waste Streams . . . . . . . . . . . . . . . . . . . . . . . . . . . 24

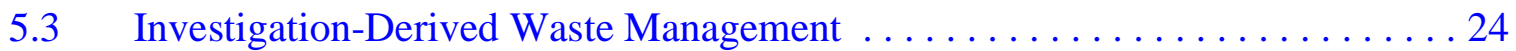

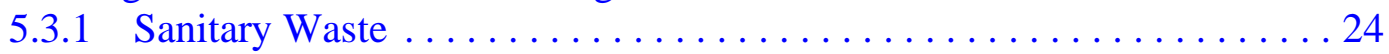

5.3.2 Low-Level Radioactive Waste . . . . . . . . . . . . . . . . . . . . 24

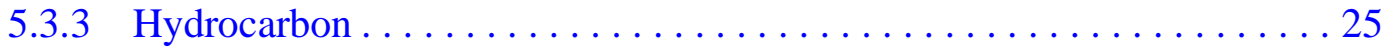

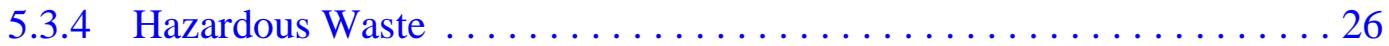

5.3 .5 Mixed Waste.................................. 27

$6.0 \quad$ Duration and Records Availability .............................. 29

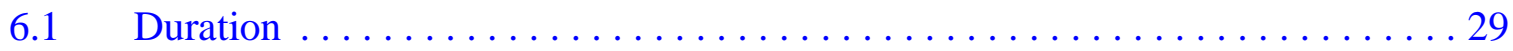

$6.2 \quad$ Records Availability................................. 29

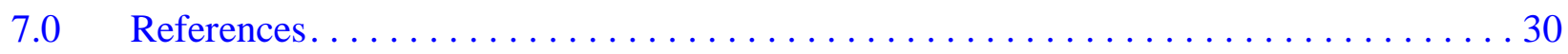

Appendix A - Data Quality Objectives Worksheets ..................... A-1

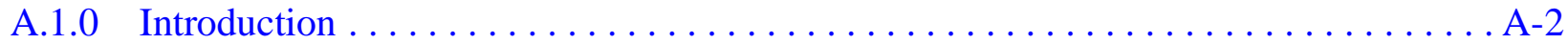

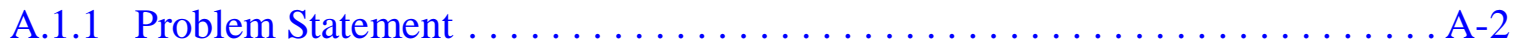

A.1.2 DQO Kickoff Meeting $\ldots \ldots \ldots \ldots \ldots \ldots \ldots \ldots \ldots \ldots \ldots \ldots \ldots \ldots \ldots \ldots \ldots \ldots \ldots \ldots, 2$

A.2.0 Conceptual Model .................................. A-4

A.3.0 Potential Contaminants . . . . . . . . . . . . . . . . . . . . . . . . A -9

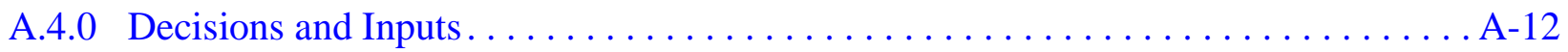

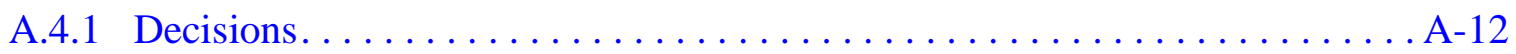

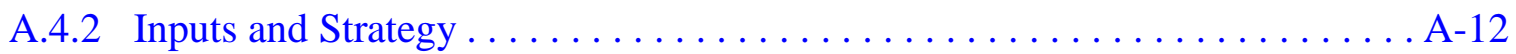

A.5.0 Investigation Strategy . . . . . . . . . . . . . . . . . . . . . . 16

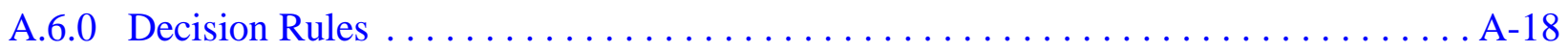

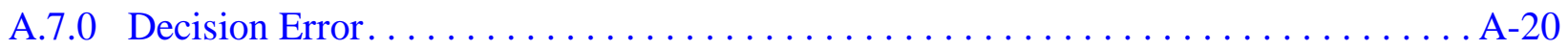

A.7.1 Confidence Levels for Volatile Organic Compounds Analysis . . . . . . . . . A-20

A.8.0 References.................................... A-22

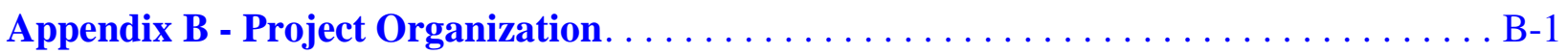

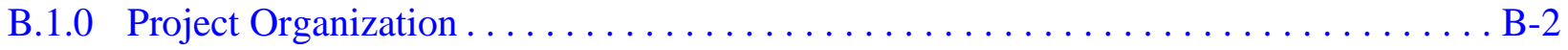




\section{Table of Contents (Continued)}

Appendix C - Laboratory Chemical, Toxicity Characteristic Leaching Procedure, and Radiochemistry Analytical Requirements for Industrial Sites . . . . . . . . . . . C-1

C.1.0 References.......................

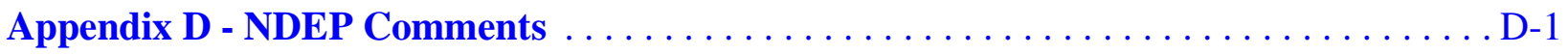




\section{List of Figures}

Number

Title

Page

1-1 Nevada Test Site and CAU 232, Area 25 Sewage Lagoons Location Map, Nye County, Nevada . . . . . . . . . . . . . . . . . . . . . . . . 2

1-2 CAU 232, Area 25 Sewage Lagoons, CAS 25-03-01 Nevada Test Site. . . . . . . . 3

2-1 Photo taken on 03/05/97 facing northwest. The east lagoon is in the foreground and Test Cell ' $\mathrm{C}$ ' Facility is in the background .................. 7

2-2 Photo taken on 09/18/97 facing northwest. The east lagoon is in the foreground. The iron outlet pipe can be seen in the west lagoon in the background and the iron overflow pipe connecting the two lagoons can be seen in the foreground. . . . . . . . . . . . . . . . . . . . . 8

2-3 Test Cell 'C' Facility Building Layout, CAU 232, Area 25 Sewage Lagoons, Nye County, Nevada . . . . . . . . . . . . . . . . . . . . . 9

2-4 Aerial photograph of CAU 232, Area 25 Sewage Lagoons. View is facing east. The west lagoon contains liquid. Photo taken in $1973 \ldots \ldots \ldots \ldots \ldots \ldots$. . . . 10

2-5 Staining and remains of waste are under the discharge pipe in the west lagoon. A preliminary field investigation describes the waste as appearing to be human waste and associated paper products. Photo taken on 09/18/97 . . . . . . 11

2-6 Outfall swale located approximately 500 feet southwest of the sewage lagoons. Photo taken on $01 / 07 / 99$ facing west. . . . . . . . . . . . . . . 12

4-1 CAU 232, Area 25 Sewage Lagoons, Proposed Sample Locations, Nye County, Nevada . . . . . . . . . . . . . . . . . . . . . 18 


\section{List of Tables}

Number

4-1 General Geotechnical and Hydrological Analyses for CAU $232 \ldots \ldots \ldots \ldots$

A.1-1 DQO Kickoff Meeting Participants........................ A-3

A.2-1 Conceptual Model For CAU 232, Area 25 Sewage Lagoons . . . . . . . . . . . . A-5

A.3-1 Contaminants of Potential Concern. ..................... A-11

A.4-1 Decisions, Inputs, and General Strategies . . . . . . . . . . . . A-13

C.1-1 Laboratory Chemical, Toxicity Characteristic Leaching Procedure, and Radiochemistry Analytical Requirements for Industrial Sites . . . . . . . . . C-2 


\section{List of Acronyms and Abbreviations}

bgs Below ground surface

BN Bechtel Nevada

CADD Corrective Action Decision Document

CAIP Corrective Action Investigation Plan

CAS Corrective Action Site(s)

CAU Corrective Action Unit

CFR Code of Federal Regulations

COC Contaminants of concern

COPC Contaminant(s) of potential concern

CV Coefficient(s) of variation

DOE U.S. Department of Energy

DOE/NV U.S. Department of Energy, Nevada Operations Office

DOT U.S. Department of Transportation

DQO Data Quality Objective(s)

EPA U.S. Environmental Protection Agency

ERD Environmental Restoration Division

FFACO Federal Facility Agreement and Consent Order

FSL Field screening levels

$\mathrm{ft} \quad$ Foot (feet)

HASP Health and Safety Plan

HWAA Hazardous waste accumulation area

IDW Investigation-derived waste

in. $\quad \operatorname{Inch}(\mathrm{es})$

ISMS Integrated Safety Management System

ITLV IT Corporation, Las Vegas

LLW Low-level radioactive waste 


\title{
List of Acronyms and Abbreviations (Continued)
}

\author{
$\mathrm{mg} / \mathrm{kg} \quad$ Milligram(s) per kilogram \\ mi Mile(s) \\ MS/MSD Matrix spike/matrix spike duplicate \\ NAC Nevada Administrative Code \\ NaI Sodium Iodide \\ NDEP Nevada Division of Environmental Protection \\ NEPA National Environmental Policy Act \\ NRC U.S. Nuclear Regulatory Commission \\ NRDS Nuclear Rocket Development Station \\ NTS Nevada Test Site \\ NTSWAC Nevada Test Site Waste Acceptance Criteria \\ PAL Preliminary action level(s) \\ PCB Polychlorinated biphenyl(s) \\ PPE Personal protective equipment \\ ppm Part(s) per million \\ PRG Preliminary remediation goal(s) \\ $\mathrm{Pu} \quad$ Plutonium \\ QA/QC Quality assurance/quality control \\ QAPP Quality Assurance Project Plan \\ RADSAFE Radiological Safety \\ RCA Radioactive Controlled Area \\ RCRA Resource Conservation and Recovery Act \\ RMA Radioactive Materials Area \\ RSD Relative standard deviation \\ $\mathrm{Sr} \quad$ Strontium
}

SSHASP Site-specific health and safety plan 


\section{List of Acronyms and Abbreviations (Continued)}

SVOC Semivolatile organic compound(s)

TCC Test Cell 'C'

TID Tamper-indicating device(s)

TPH Total petroleum hydrocarbon(s)

U Uranium

VOC Volatile organic compound(s) 


\section{Executive Summary}

The Corrective Action Investigation Plan for Corrective Action Unit 232, Area 25 Sewage Lagoons, has been developed in accordance with the Federal Facility Agreement and Consent Order that was agreed to by the U.S. Department of Energy, Nevada Operations Office; the State of Nevada Division of Environmental Protection; and the U. S. Department of Defense. Corrective Action Unit 232 consists of Corrective Action Site 25-03-01, Sewage Lagoon.

Corrective Action Unit 232, Area 25 Sewage Lagoons, received sanitary effluent from four buildings within the Test Cell 'C' Facility from the mid-1960s through approximately 1996. The Test Cell 'C' Facility was used to develop nuclear propulsion technology by conducting nuclear test reactor studies.

Based on the site history collected to support the Data Quality Objectives process, contaminants of potential concern include volatile organic compounds, semivolatile organic compounds, Resource Conservation and Recovery Act metals, petroleum hydrocarbons, polychlorinated biphenyls, pesticides, herbicides, gamma emitting radionuclides, isotopic plutonium, isotopic uranium, and strontium-90. A conceptual site model for the Corrective Action Unit was developed and is summarized as follows:

- Contaminants of potential concern, if present, are associated with sanitary effluent and/or with the unintentional release of contaminants from the Test Cell ' $\mathrm{C}$ ' Facility buildings that were serviced by the sewage lagoons.

- Contamination within the sewage lagoons, if present, will be confined within the boundaries of the sewage lagoons.

- Radionuclides, although not anticipated, may be present due to activities related to the Nuclear Rocket Development Station program and with use of the Radiological Safety trailer at the Test Cell 'C' Facility.

- Contaminants of potential concern at the sewage lagoons are limited vertically to less than 3 feet and laterally within the bermed area.

- Extent of contamination in the swale, if any, is unknown. Potential exists for down-gradient migration. 
- Groundwater impacts are not anticipated because the water level of the nearest well is approximately 1,000 feet.

- Exposure pathways are ingestion, inhalation, and dermal contact.

A more detailed conceptual site model is presented in Section 3.0 and Section A.2.0 of Appendix A of this Corrective Action Investigation Plan. The conceptual model serves as the basis for the sampling strategy.

The technical approach for investigating this Corrective Action Unit consists of the following activities:

- Collect surface and subsurface samples using a direct-push method.

- Conduct field screening to direct sampling activities and provide a qualitative assessment of conditions.

- Collect samples from step-out locations, as necessary, to define the extent of the contaminants of potential concern, if present.

- Conduct laboratory analysis of selected environmental samples.

- If necessary, conduct a Stage II field investigation using drilling to investigate the vertical and/or lateral extent of contaminants of potential concern that may exist beyond the reach of the direct-push method.

Additional sampling and analytical details are presented in Section 4.0, and details of the waste management strategy are included in Section 5.0 of this Corrective Action Investigation Plan.

Under the Federal Facility Agreement and Consent Order, the Corrective Action Investigation Plan will be submitted to the Nevada Division of Environmental Protection for approval. Field work will be conducted following approval of the plan. The results of the field investigation will support a defensible evaluation of corrective action alternatives in the Corrective Action Decision Document. 


\subsection{Introduction}

This Corrective Action Investigation Plan (CAIP) has been developed in accordance with the Federal Facility Agreement and Consent Order (FFACO) (1996) that was agreed to by the U.S. Department of Energy, Nevada Operations Office (DOE/NV); the State of Nevada Division of Environmental Protection (NDEP); and the U.S. Department of Defense. The CAIP is a document that provides or references all of the specific information for investigation activities associated with Corrective Action Units (CAUs) or Corrective Action Sites (CASs). According to the FFACO, CASs are sites potentially requiring corrective action(s) and may include solid waste management units or individual disposal or release sites. A CAU consists of one or more CASs grouped together based on geography, technical similarity, or agency responsibility for the purpose of determining corrective actions.

This CAIP contains the environmental sample collection objectives and criteria for conducting site investigation activities at CAU 232, Area 25 Sewage Lagoons. Corrective Action Unit 232 consists of CAS 25-03-01, Sewage Lagoon, located in Area 25 of the Nevada Test Site (NTS). The NTS is approximately 65 miles (mi) northwest of Las Vegas, Nevada (Figure 1-1) (DOE/NV, 1996a). The Area 25 Sewage Lagoons (Figure 1-2) (IT, 1999b) are located approximately 0.3 mi south of the Test Cell 'C' (TCC) Facility and were used for the discharge of sanitary effluent from the TCC facility. For purposes of this discussion, this site will be referred to as either CAU 232 or the sewage lagoons.

\subsection{Purpose}

This CAIP presents a plan to investigate CAU 232. The purpose of the corrective action investigation is as follows:

- Identify the presence and nature of contaminants of potential concern (COPCs).

- Determine the vertical and lateral extent of COPCs.

- Provide sufficient information and data to determine the need for corrective actions. Develop and evaluate appropriate corrective actions for the sewage lagoons. 


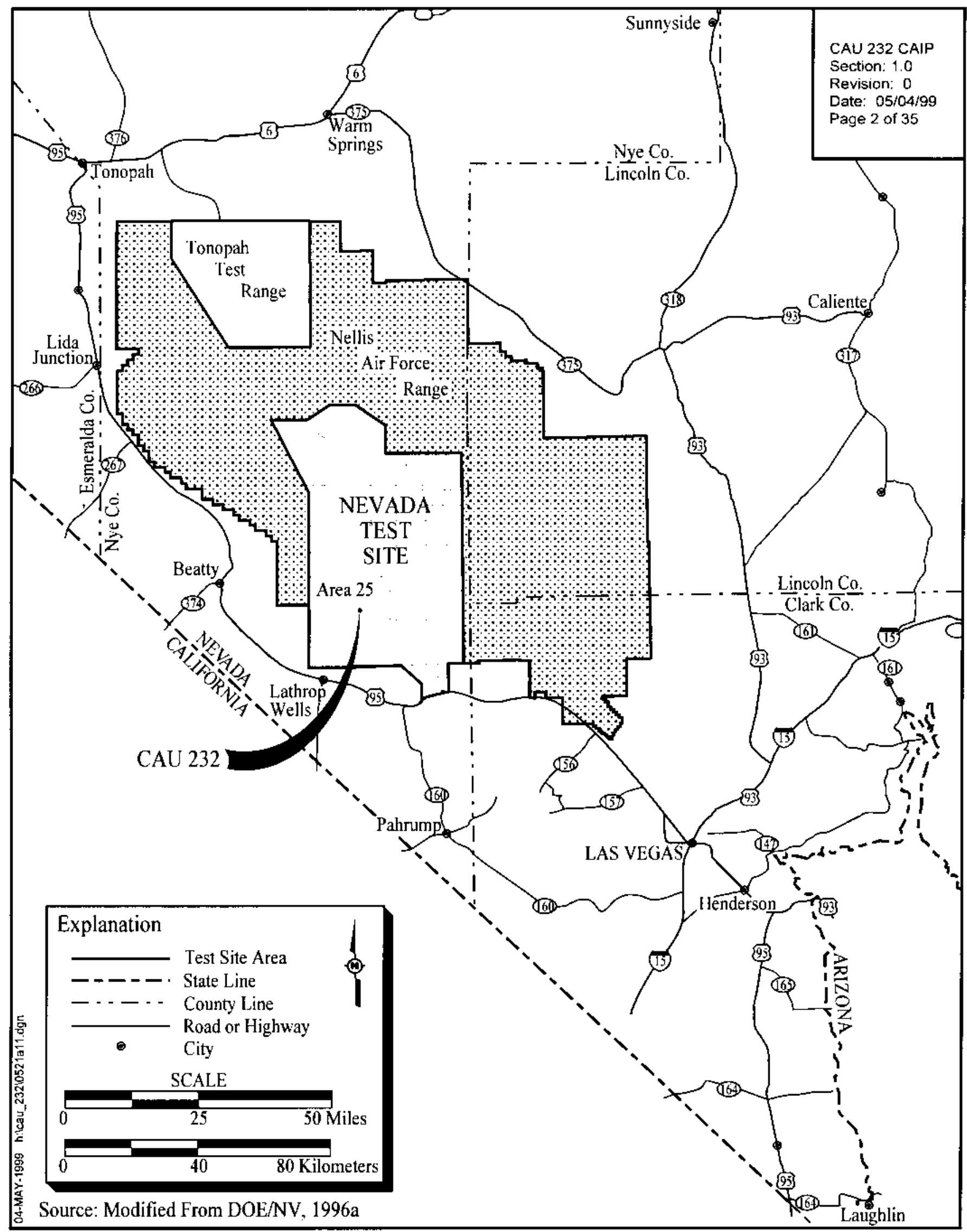

Figure 1-1

Nevada Test Site and CAU 232, Area 25 Sewage Lagoons Location Map,

Nye County, Nevada 


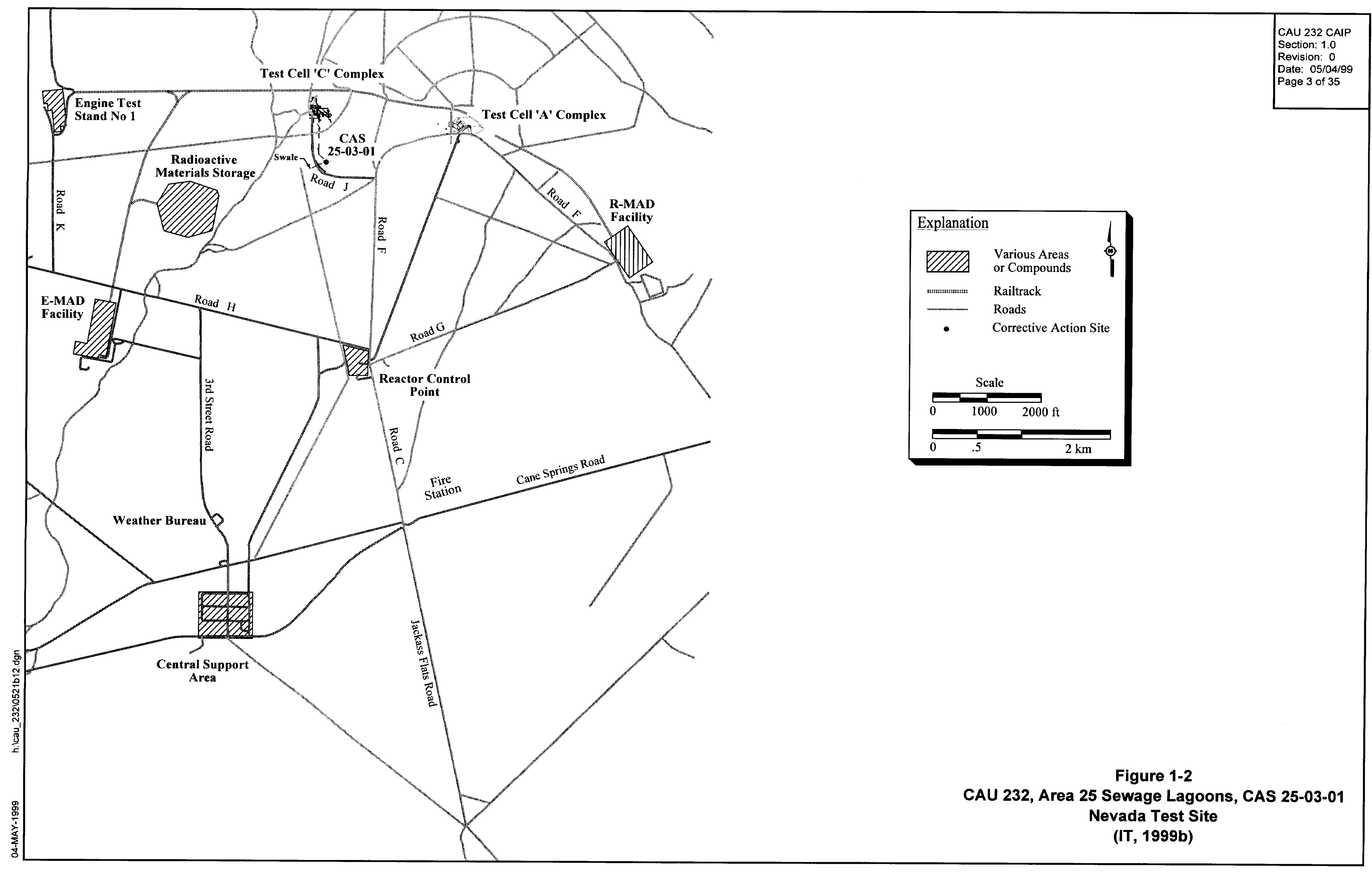


This CAIP was developed using the U.S. Environmental Protection Agency's (EPA) Data Quality Objectives (DQOs) (EPA, 1994) process to clearly define the goals and set the DQOs for collecting environmental data and to design a data collection program that will satisfy these goals. A DQO scoping meeting was held prior to preparation of this plan; a brief summary of the DQO process is presented in Section 3.4.

\subsection{Scope}

The scope of this CAIP is to resolve the problem statement identified during the DQO process, which states that sanitary effluent was discharged from various buildings located within TCC to the sewage lagoons and that contaminants may have been discharged into the sewage lagoons as well. Existing information regarding the nature and extent of contamination is insufficient to evaluate and select preferred corrective actions for this site. Therefore, the scope of the corrective action investigation for the sewage lagoons includes the following tasks:

- Determine if contamination is present at CAU 232 by:

- Statistically generating a minimum number of sample locations to increase the level of certainty of finding COPCs, if any. These sample locations will be selected in likely worst-case areas.

- Collecting soil samples using a direct-push method (such as the Geoprobe ${ }^{\circledR}$ ).

- Utilizing field-screening methods to determine the presence of COPCs and to guide the investigation.

- Determine the nature and extent of COPCs, if any, by:

- Identifying the types and concentrations of COPCs through field and laboratory analytical methods and techniques.

- Determining the lateral and vertical extent through additional sampling, as needed, if COPCs above field-screening or preliminary action levels are found. 


\subsection{CAIP Contents}

Section 1.0 of this CAIP provides an introduction to this project, including the purpose and scope for this corrective action investigation. The remainder of the document details the investigation strategy and complies with the following FFACO-required elements:

- Management

- Technical aspects

- Quality assurance

- Health and safety

- Public involvement

- Field sampling

- Waste management

The managerial aspects of this project are discussed in the DOE/NV Project Management Plan (DOE/NV, 1994a) and the site-specific Field Management Plan that will be developed prior to field activities. The technical aspects of this CAIP are contained in Section 3.0 and Section 4.0 of this document and in the DQO summary presented in Appendix A. General field and laboratory quality assurance and quality control (QA/QC) issues, including collection of QC samples, are presented in the Industrial Sites Quality Assurance Project Plan (QAPP) (DOE/NV, 1996b); the methods for field QA/QC are discussed in approved procedures. The general health and safety aspects of this project are discussed in the Environmental Restoration Project Health and Safety Plan (HASP) (DOE/NV, 1998b) and will also be supplemented with a site-specific HASP (SSHASP) written and approved prior to the start of field work. No CAU-specific public involvement activities are planned at this time; however, an overview of public involvement is documented in the "Public Involvement Plan" in Appendix V of the FFACO (1996). Field sampling activities are discussed in Section 4.0 of this CAIP; waste management issues are discussed in Section 5.0. The project schedule and records availability information for this CAIP are discussed in Section 6.0, and Section 7.0 provides a list of project references. 


\subsection{Facility Description}

\subsection{Physical Setting}

The CAU 232 sewage lagoons are located approximately $0.3 \mathrm{mi}$ south of the TCC Facility at the NTS. The sewage lagoons (pictured in Figures 2-1 and 2-2) (IT, 1997a and 1997b) were designed to receive sanitary sewage generated at TCC. The TCC buildings serviced by the sewage lagoons were 3220 (Equipment \& Pump House), 3224 (Restroom), 3229 (Operations), and the former Radiological Safety (RADSAFE) Check Station trailer. A generalized schematic of the TCC Facility relative to the sewage lagoons is presented in Figure 2-3 (IT, 1999e). The approximate outside dimensions for the west and east sewage lagoons are $100 \times 60 \mathrm{feet}(\mathrm{ft})$ and $100 \times 50 \mathrm{ft}$, respectively, and are separated approximately $15 \mathrm{ft}$. Each sewage lagoon is approximately $5 \mathrm{ft}$ deep. A swale located approximately $500 \mathrm{ft}$ southwest of the sewage lagoons may have served as an outfall in the event that capacity of the sewage lagoons was exceeded.

\subsection{Operational History}

Area 25 was historically used for nuclear propulsion studies using KIWI and Phoebus test reactors from the mid-1960s through approximately 1973 (Sanders, 1968 and DOE/NV, 1984).

Decontamination and decommissioning activities took place until 1983 and included radiological surveys of particular areas and facilities within Area 25. Remediation of contaminated soil at TCC was performed intermittently from 1978 through 1984 (Sanders, 1968 and DOE/NV, 1984). No information was identified indicating that the sewage lagoons were ever contaminated or were part of the decontamination process.

The sewage lagoons were constructed around 1966 (REECo, 1966) and used from 1966 until approximately 1988. Upgrades and modifications were made to the sewage lagoons in July 1991. The sewer system was used intermittently from 1992 through 1996 by U.S. Geological Survey personnel who were using the TCC Building 3229 as office space (Edwards, 1998). The use of the sewage lagoons was terminated in the Spring of 1996 when the TCC water supply system failed to pass a sanitary survey due to inadequate potable water and sewage treatment systems (BN, 1997). A request to terminate the sewage lagoon permit was submitted by Bechtel Nevada (BN) to the 


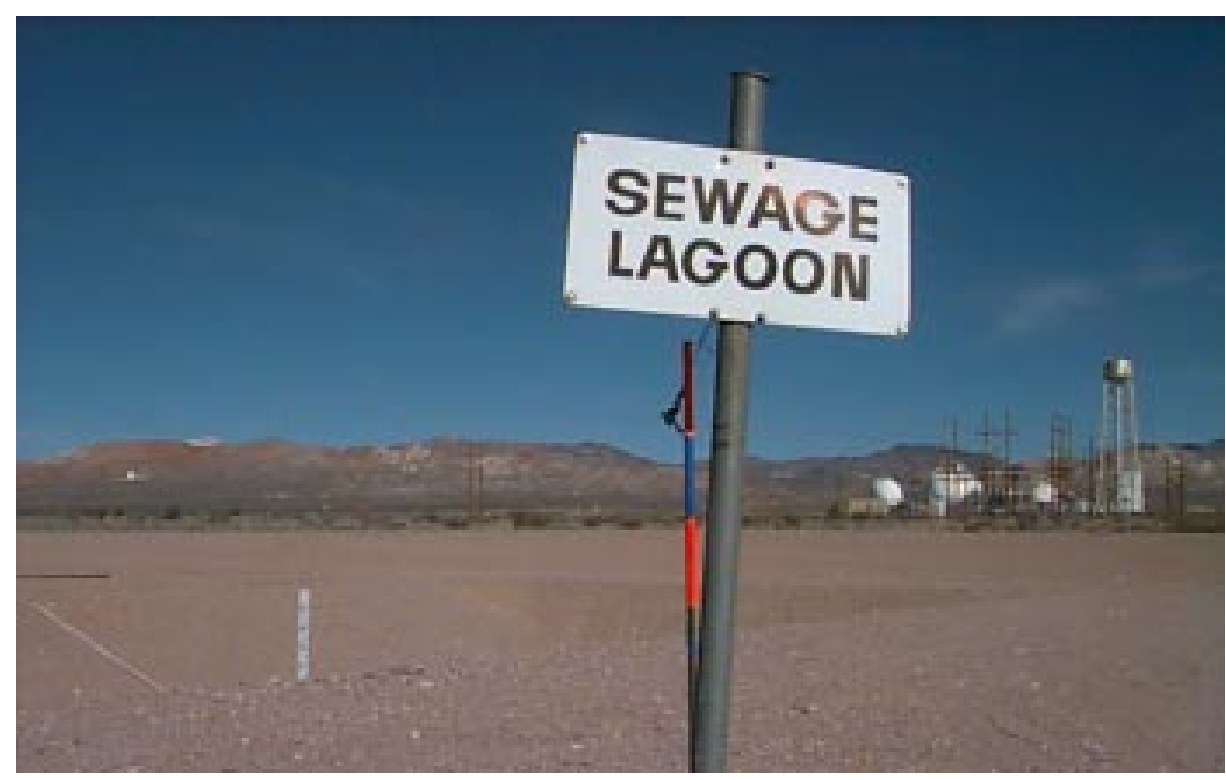

Figure 2-1

Photo taken on $03 / 05 / 97$ facing northwest.

The east lagoon is in the foreground and Test Cell ' $C$ ' Facility is in the background. (IT, 1997a)

DOE/NV on March 3, 1997. The sewage lagoons were removed from the permit on April 30, 1997 (van Drielen, 1997).

\subsection{Waste Inventory}

Engineering drawings show that the four TCC buildings are connected to the sewage lagoons by a 6-inch (in.) vitrified clay pipe (REECo, $1984 \mathrm{a}$ and b), but no additional information has been located that would provide the exact dates of use and the associated quantity of effluent discharged into the sewage lagoons. An aerial photograph taken in 1973 (EG\&G/EM, 1973) (Figure 2-4) shows liquid in the west sewage lagoon. No documentation was found to substantiate that the east sewage lagoon had ever been used. Examination of photographs shows that the east lagoon is dry and that there is no apparent staining. In addition, there is no evidence that the swale (Figure 2-6) (IT, 1999c) located approximately $500 \mathrm{ft}$ southwest of the sewage lagoons had ever received effluent. Uses for the RADSAFE Check Station trailer, and Buildings 3229 (Operations) and 3220 (Equipment and Pump House) have not been confirmed. 


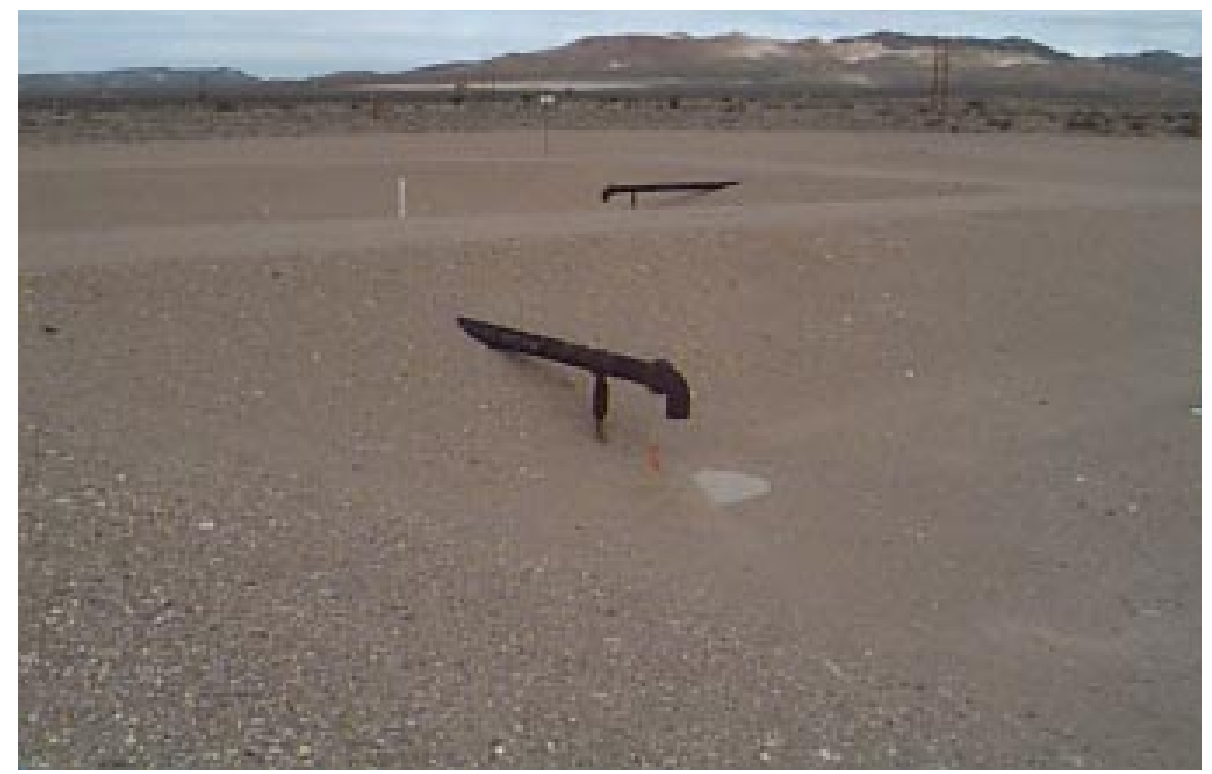

Figure 2-2

Photo taken on 09/18/97 facing northwest. The east lagoon is in the foreground. The iron outlet pipe can be seen in the west lagoon in the background and the iron overflow pipe connecting the two lagoons can be seen in the foreground. (IT, 1997b)

\subsection{Release Information}

No documented evidence has been found indicating any COPC release(s). The use of pesticides, herbicides, rodenticides (Moore, 1998 and Bielawski, 1998) and algaecides (Frazier, 1988) are standard practice for the operation of sewage lagoons at the NTS and, while these constituents may be present, they are not expected to be found at concentrations exceeding preliminary action levels (PALs). The sewage lagoon(s) received 29,000 gallons of liquid from Area 25 Reactor Control Point sewage lagoons over a two-month period in 1995 (BN, 1996). Constituents of the liquid received from the Area 25 Reactor Control Point are unknown, but action levels required by the Water Pollution Control Permit were not exceeded.

\subsection{Investigative Background}

Two preliminary soil samples were collected from the sewage lagoons (one sample from each lagoon) by IT Corporation, Las Vegas (ITLV) personnel on August 27, 1997, and analyzed by 


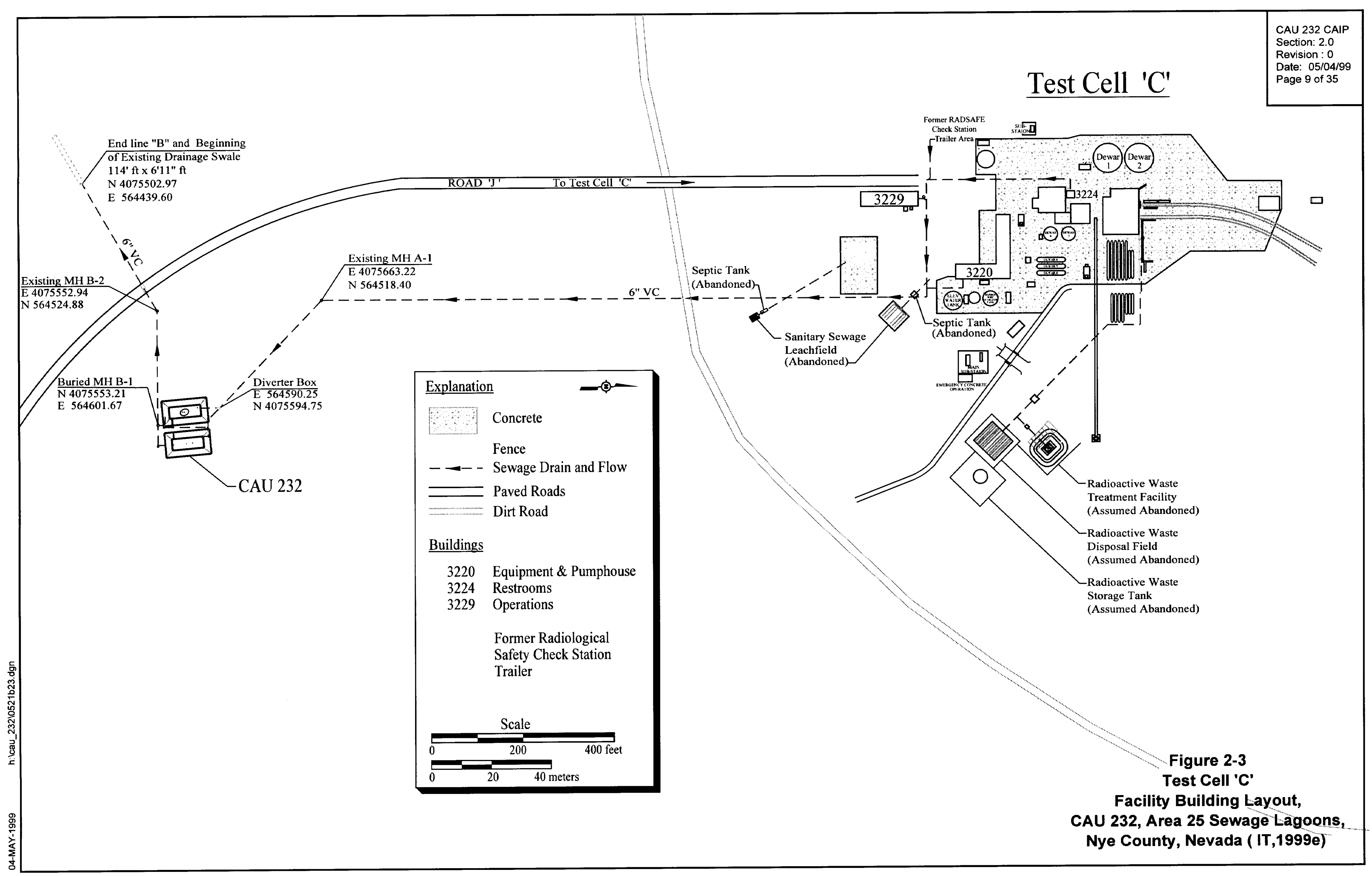




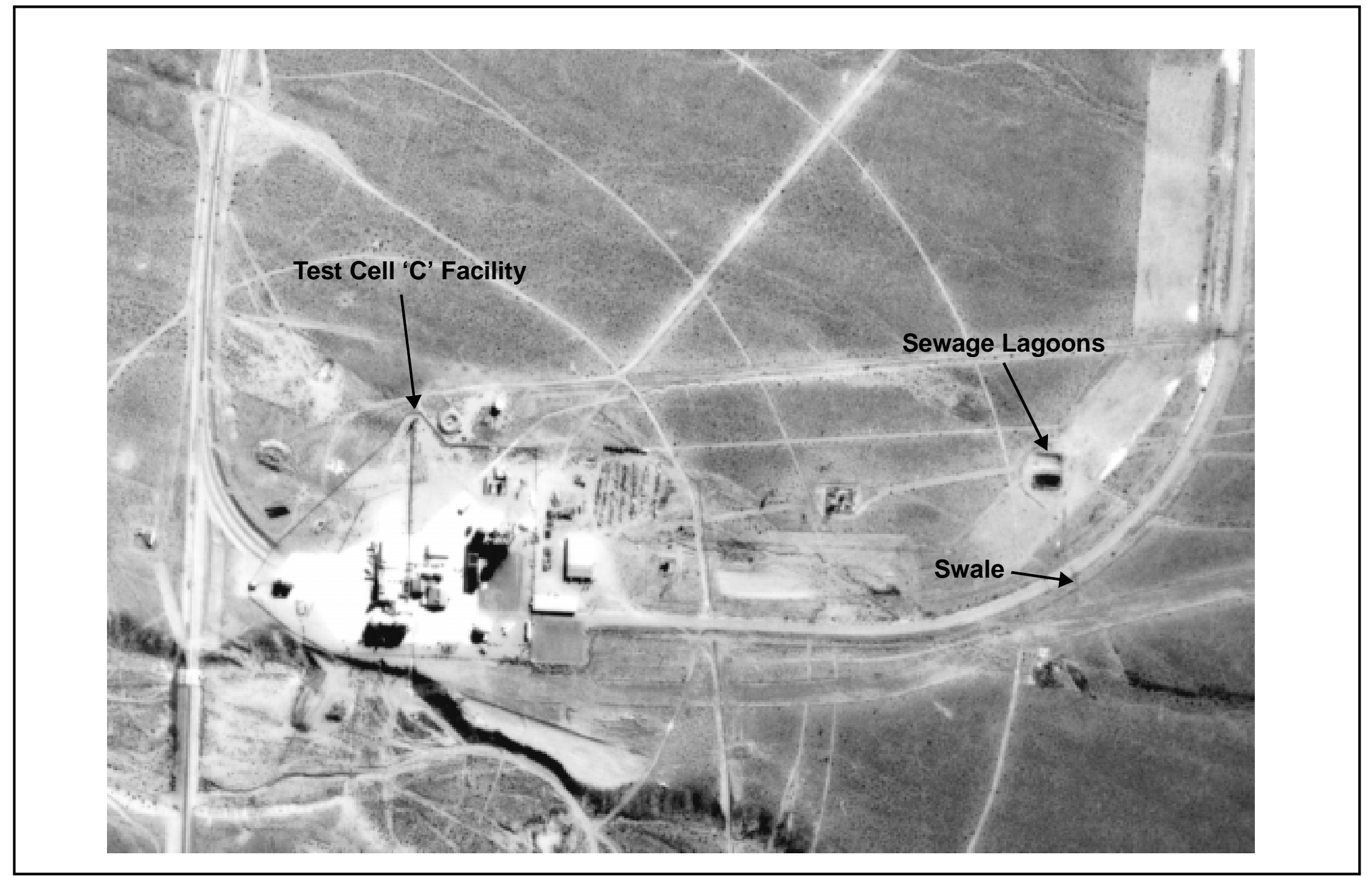

Figure 2-4

Aerial photograph of CAU 232, Area 25 Sewage Lagoons. View is facing east. The west lagoon contains liquid. Photo taken in 1973. (EG\&G/EM, 1973) 


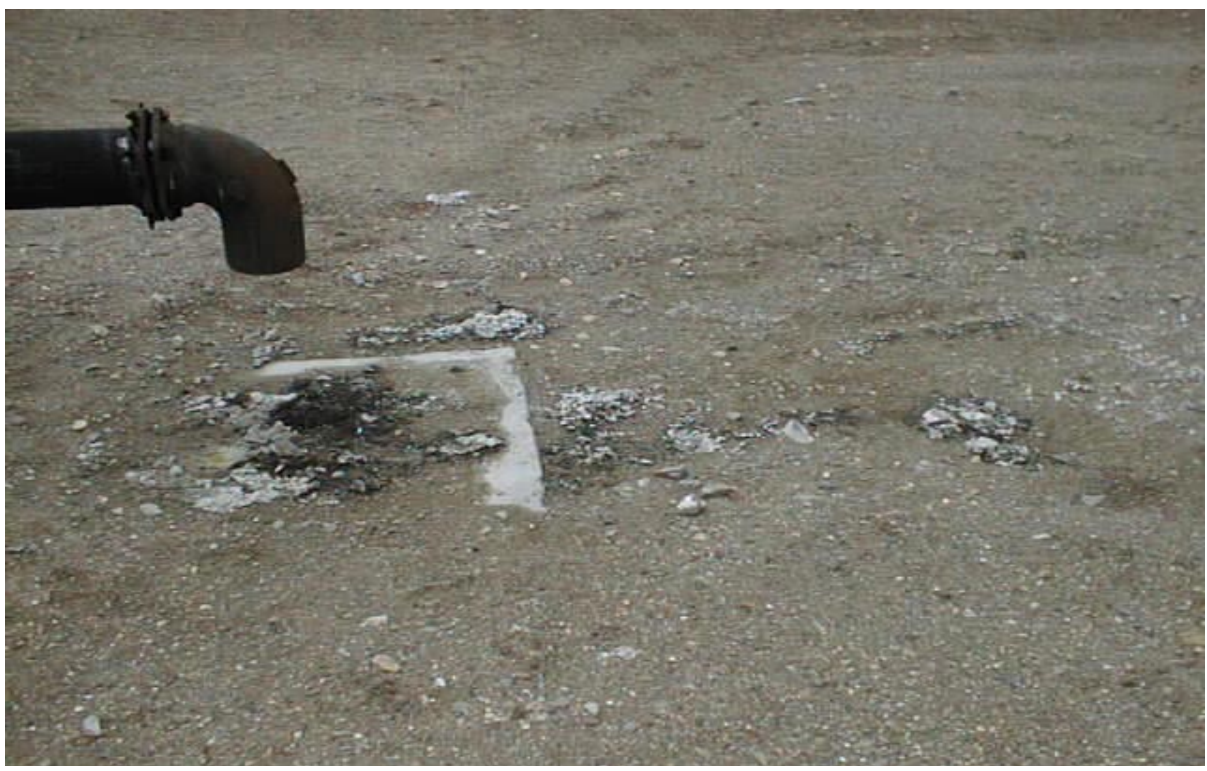

Figure 2-5

Staining and remains of waste are under the discharge pipe in the west lagoon. A preliminary field investigation describes the waste as appearing to be human waste and associated paper products. Photo taken on 09/18/97. (IT, 1997c)

Quanterra Environmental Services in St. Louis, Missouri (Hersh, 1998). The intent of the preliminary sampling activity was to collect soil samples from areas within the sewage lagoons considered most likely to be contaminated to identify COPCs. Sample ERS00165 was collected from the outfall area of the inlet pipe in the west lagoon and sample ERS00166 was collected from the outfall area of the inlet pipe in the east lagoon. The samples were analyzed for total volatile organic compounds (VOCs), total semivolatile organic compounds (SVOCs), total pesticides, total petroleum hydrocarbons (TPH), total Resource Conservation and Recovery Act (RCRA) metals, polychlorinated biphenyls (PCBs), gross alpha and beta emitters, and gamma emitting isotopes. Arsenic was the only COPC identified above the preliminary remediation goals (PRGs) with a reading of 3.1 milligrams per kilogram (mg/kg) in sample ERS00165. The PRG for arsenic is $3.0 \mathrm{mg} / \mathrm{kg}$ (EPA, 1998); however, arsenic at this concentration is not unusual in the state of Nevada (NBMG, 1998).

Site investigation activities associated with CAU 232 have been identified and documented in the Final Environmental Impact Statement for the Nevada Test Site and Off-Site Locations in the State of Nevada (DOE/NV, 1996a). In accordance with the DOE/NV National Environmental Policy Act 


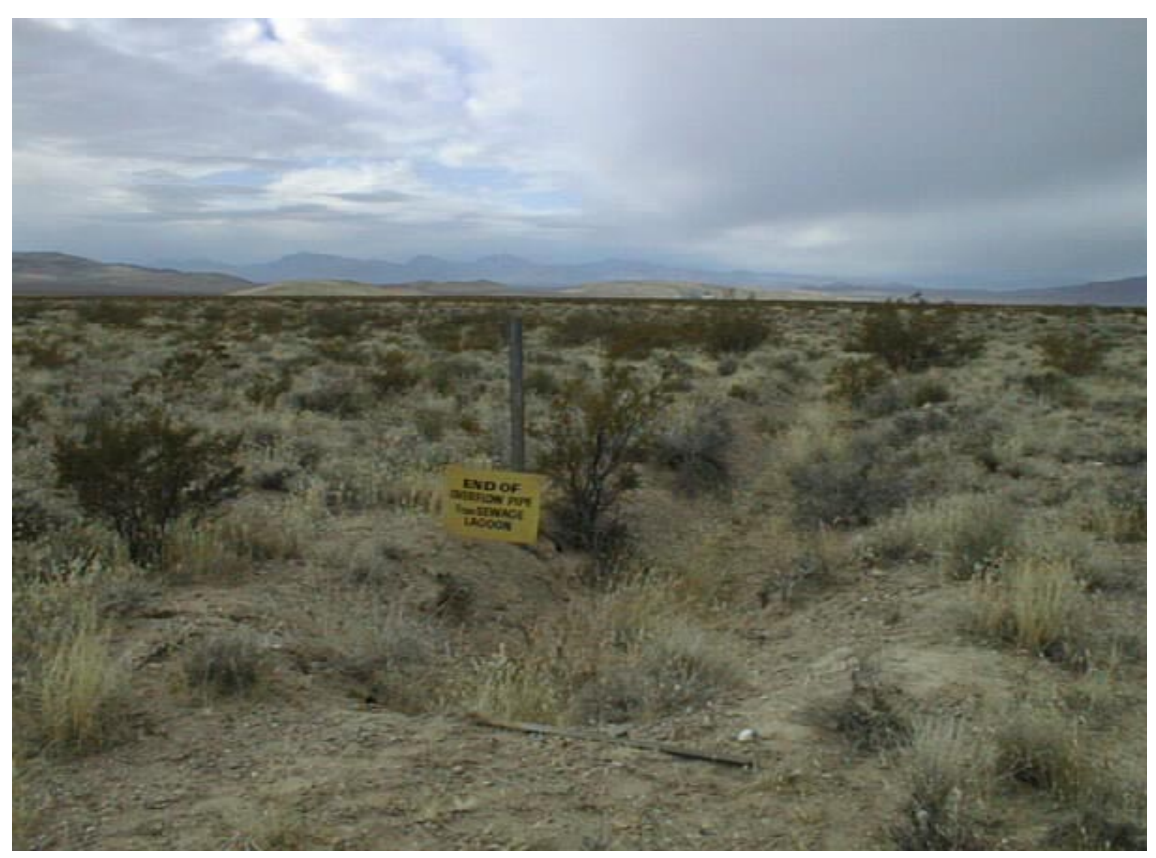

Figure 2-6

\section{Outfall swale located approximately 500 feet southwest of the sewage lagoons. Photo taken on 01/07/99 facing west. (IT, 1999c)}

(NEPA) compliance program, a NEPA checklist shall be completed prior to commencement of site investigation activities at this CAU site. This checklist compels DOE/NV to evaluate this proposed project against a list of several potential environmental impacts which include, but are not limited to, air quality, chemical use, waste generation, noise level, and land use. Completion of the checklist results in a determination of the appropriate level of NEPA documentation by the DOE/NV NEPA Compliance Officer for this project. 


\subsection{Objectives}

The DQOs are qualitative and quantitative statements that specify the quality of the data required to support potential corrective action(s) for CAU 232. The DQOs were developed to clearly define the purposes for which environmental data will be used and to design a data collection program that will satisfy these purposes. The formulation of a conceptual site model is an aid to the development of DQOs for the site.

\subsection{Conceptual Site Model}

The conceptual site model for the Sewage Lagoons in the DQO process is presented in Appendix A and is summarized as follows:

- The COPCs, if present, are associated with sanitary effluent and/or with the unintentional release of contaminants from the TCC Facility buildings that were serviced by the sewage lagoons.

- Contamination within the sewage lagoons, if present, will be confined within the boundaries of the sewage lagoons.

- Radionuclides, although not anticipated, may be present due to activities related to the Nuclear Rocket Development Station (NRDS) program and with use of the RADSAFE trailer at the Test Cell 'C' Facility.

- $\quad$ The COPCs at the sewage lagoons are limited vertically to less than $3 \mathrm{ft}$ and laterally within the bermed area.

- Extent of contamination in the swale, if any, is unknown. Potential exists for down-gradient migration.

- Exposure pathways are ingestion, inhalation, and dermal contact.

Groundwater impact is unlikely because the depth to groundwater is extensive (approximately $1,000 \mathrm{ft}$ at the nearest well [Hale and Westenburg, 1995]) and the environmental conditions at the site (i.e., arid climate, high evaporation) are not conducive to downward migration of COPCs. 


\subsection{Contaminants of Potential Concern}

The following list of COPCs is based on the process knowledge that the site was used for sanitary effluent and was servicing TCC buildings associated with the NRDS program:

- VOCs, SVOCs, RCRA metals, petroleum hydrocarbons (diesel- and gasoline-range organics), PCBs, pesticides, herbicides, gamma emitting radionuclides, isotopic Plutonium $(\mathrm{Pu})$, isotopic Uranium (U), Strontium (Sr-90)

The COPCs are expected to be within the typical NTS backgrounds and are not expected to exceed PALs at this site.

\subsection{Preliminary Action Levels}

Field screening levels (FSLs) for on-site field screening methods are provided in Table A.3-1 in Appendix A. The PALs for off-site laboratory analytical methods will be used to determine the presence of contamination and will be conducted in accordance with the requirements in Appendix C.

\subsubsection{Field Screening Levels}

The following field screening levels will be used for on-site field screening methods:

- The VOC headspace screening levels are established at 20 parts per million (ppm) or 2.5 times background, whichever is greater, using a photoionization detector.

- The radiation (alpha/beta and gamma) screening levels are defined as the mean surficial-background activity level plus two times the standard deviation of the mean surficial-background activity level.

Details of the methodology to determine the radiological field screening levels can be found in Table A.3-1 of the DQO worksheet in Appendix A.

Concentrations exceeding FSLs will indicate potential contamination at that particular sample location. This information will be documented, and the investigation will continue to delineate the extent of the contamination as necessary. Additionally, these field screening data will be used to select discretionary samples to be submitted to the laboratory. 


\subsubsection{Chemical Preliminary Action Levels}

Off-site laboratory analytical results will be compared to the following PALs to evaluate the need for possible corrective actions:

- The NDEP Corrective Action Regulations (NAC, 1998a) (for purposes of this CAIP, Region IX PRGs for industrial soils are assumed as the PALs [EPA, 1998])

- Total petroleum hydrocarbons concentrations above the TPH limit of 100 ppm per the Nevada Administrative Code (NAC) 445A.2272 (NAC, 1998a)

Laboratory results will be compared to the PALs and discussed in the Corrective Action Decision Document (CADD). Laboratory results above PALs indicate the presence of COPCs at levels that may require corrective action. The evaluation of potential corrective actions and the justification for a preferred action will be included in the CADD based on the results of this field investigation.

\subsubsection{Radiological Preliminary Action Levels}

The PALs for radionuclides are isotope-specific and are defined as the maximum concentration for that isotope found in environmental samples taken from undisturbed background locations.

Environmental background samples will be taken in the vicinity of CAU 232. These samples will be analyzed and compared with the results for environmental samples taken from other undisturbed background locations in Area 25. In addition, the radionuclide concentrations in the CAU 232 and Area 25 background samples will be compared with the radionuclide concentrations found in environmental samples taken from undisturbed background locations in the vicinity of the NTS presented in McArthur and Miller (1989) and Atlan-Tech (1992). The PAL for each isotope will be the maximum concentration of that isotope found in any of the samples taken from the undisturbed background locations described above.

\subsection{DQO Process Discussion}

Details of the DQO process are presented in Appendix A. During the DQO discussions for this CAU, the need for a statistically based sampling approach was identified. This approach generated a number of sampling locations which were then selected in potential "worst-case" areas. Contamination is not expected to occur deeper than $3 \mathrm{ft}$ below ground surface (bgs) and the investigation will utilize a direct-push method to conduct soil sampling. The COPCs, analytical methods, and reporting limits prescribed through the DQO process are included in Appendix C, along with the precision and accuracy requirements stated in the latest revision of the individual EPA SW-846 methods (EPA, 1996). Resulting data will be evaluated to confirm or refute the conceptual model. 


\subsection{Field Investigation}

This section of the CAIP contains the sampling approach for investigating CAU 232. All sampling activities will be conducted in compliance with the Industrial Sites QAPP (DOE/NV, 1996b) and other applicable, approved procedures. Quality assurance and quality control requirements for field and laboratory environmental sampling are also contained in the Industrial Sites QAPP and within Appendix C. Data will be collected during field investigations to confirm or refute the conceptual model by assessing the migration of COPCs and determining if COPCs are present in concentrations exceeding the PALs established for CAU 232. Field screening techniques will assist the investigation in determining if COPCs are present. Laboratory analyses will be conducted for confirmation and verification of the field screening results.

Field activities will be performed in accordance with the current version of the HASP (DOE/NV, 1998b) and an approved SSHASP to be prepared prior to the field effort. As required by the DOE Integrated Safety Management System (ISMS) (DOE/NV, 1997a), these documents outline the requirements for protecting the health and safety of the workers and the public, and the procedures for protecting the environment. The ISMS program requires that site personnel will take every reasonable step to reduce or eliminate the possibility of injury, illness, or accidents, and to protect the environment during all project activities. The following safety issues will be taken into consideration when evaluating the hazards and associated control procedures for the field activities included and discussed in the SSHASP:

- Potential hazards to site personnel and the public including, but not limited to, radionuclides, chemicals (such as heavy metals, VOCs, SVOCs, and PCBs), adverse and rapidly changing weather, remote location, and motor vehicle and heavy equipment operations.

- Proper training of all site personnel to recognize and mitigate the anticipated hazards.

- Work controls to reduce or eliminate the hazards including engineering controls, substitution of less hazardous materials, and personal protective equipment (PPE).

- Occupational exposure monitoring to prevent overexposures to hazards such as radionuclides, chemicals, and physical agents (heat, cold, and high wind). 
- Radiological surveying for alpha/beta and gamma emitters to minimize and/or control personnel exposures. Use of the "as low as reasonably achievable" principle when dealing with radiological hazards.

- Emergency and contingency planning and communications to include medical care and evacuation, decontamination and spill control measures, and appropriate notification of project management.

\subsection{Technical Approach}

The following activities will be conducted during the site investigation:

- Collect surface and near-surface environmental samples from biased locations within the sewage lagoons and swale.

- $\quad$ Field screen for VOCs and radioactivity.

- Collect surface and near-surface background samples from nearby undisturbed locations for radioanalysis and RCRA metals comparisons.

- Conduct laboratory analysis for COPCs listed in Section 3.0, discussed in Appendix A, and included in Appendix C.

- Samples may be collected for geotechnical analysis at the discretion of the Site Supervisor.

\subsubsection{Sampling Locations}

Biased sampling locations (see Figure 4-1) (IT, 1999a) at the sewage lagoons and at the swale are described in Appendix A (Sections A.4.0, A.5.0, A.6.0, and A.7.0). The number of sampling locations was statistically generated and located in a biased manner based on a homogenous spread of potential contaminants within liquids, ponding in low lying areas, and accumulation of COPCs near outfalls.

Prior to determining the number of sample locations that would best represent potential contamination at CAU 232, a driving parameter had to be determined. Based on process knowledge, field screening will be performed for both VOCs and radionuclides. Due to the low potential for radiological contamination, VOCs were chosen as the driving parameter for investigation of the site. 


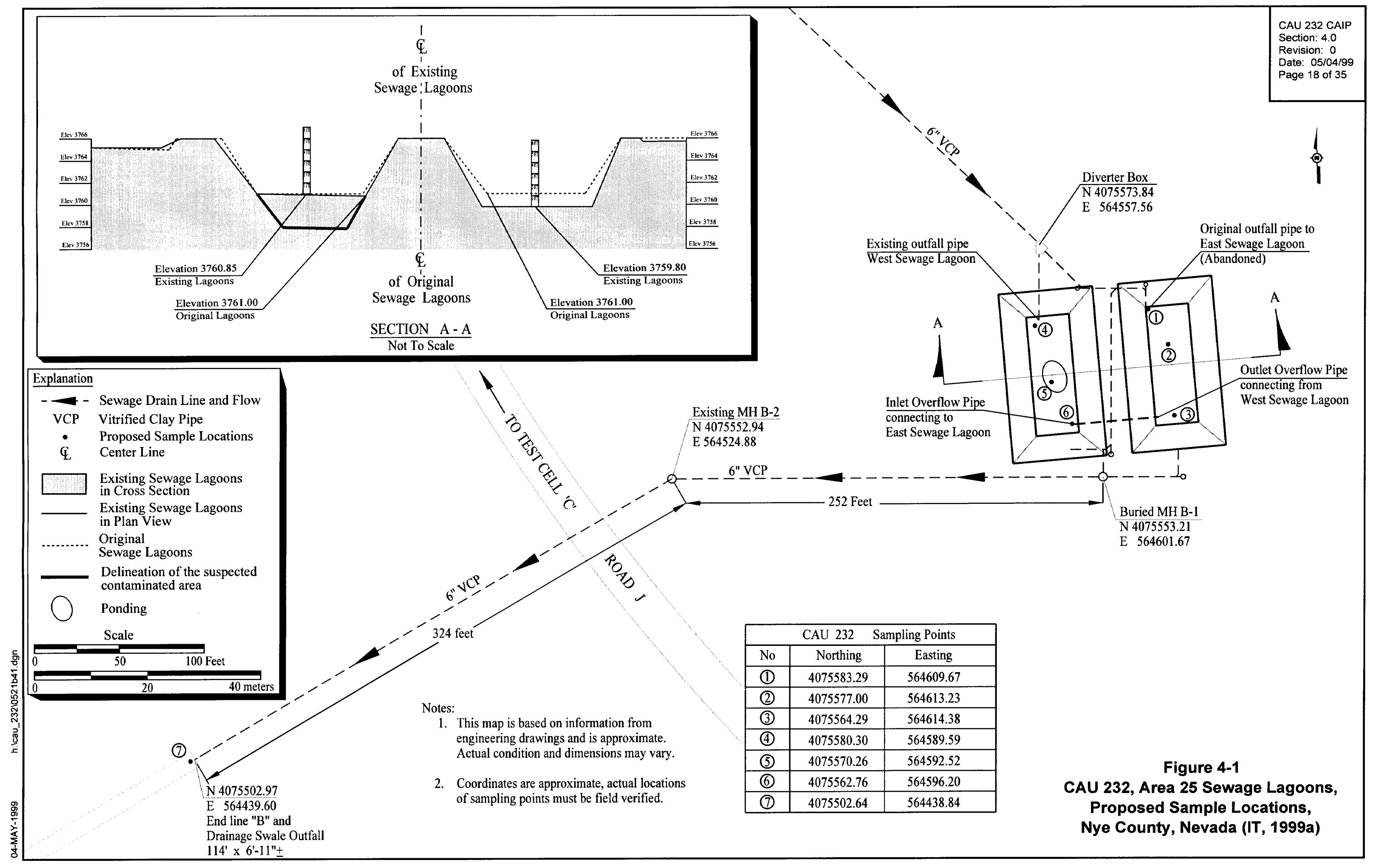


The confidence levels and sampling errors used to generate systematic random locations were agreed upon by the DOE/NV and the NDEP during the DQO process and are presented in Section A.7.1.

Inputting parameters into standard statistical equations for calculating the required number of sample locations in the sewage lagoons results in three sample locations per lagoon. In the west lagoon, one sample location has been selected at the outfall and two selected within the low lying area as shown in Figure 4-1. In the east lagoon, a sample location has been selected at each of the two outfalls and one location has been randomly selected.

In addition, one biased location has been selected at the outfall in the swale. Other sample locations may be selected during the field investigation at the discretion of the Site Supervisor. Four samples will be collected from two background locations prior to the collection of samples within the lagoons and swale.

\subsubsection{Sampling Criteria}

Soil sampling will be conducted using a Geoprobe ${ }^{\circledR}$ or other direct-push methods. Soil samples will be collected using a Macrocore ${ }^{\mathrm{TM}}$ sampling barrel (or similar) with polyvinyl chloride, stainless-steel, or other approved liners. Soil sampling and field screening intervals will be at approximately 1 -ft and 3-ft depths. Sample collection may be extended to approximately 5-ft and 8-ft depths, if field screening results exceed FSLs.

At each sample location where field screening results are above the FSLs, the sample with the highest field screening result will be submitted for laboratory analyses. In addition, two consecutive samples that have results below the FSLs will be submitted for laboratory analyses to support the field screening results. A minimum of 18 samples (not including QC samples) will be submitted for laboratory analyses.

All samples selected for laboratory analyses will be analyzed in accordance with the requirements discussed in Appendix C. Samples will be analyzed for total VOCs, total SVOCs, total RCRA metals, TPH (diesel- and gasoline-range organics), total pesticides, total herbicides, and PCBs. If radiological field screening results for a sample exceed the FSLs discussed in Section 3.3.1, then laboratory analysis for that sample will also include gamma spectrometry, isotopic $\mathrm{Pu}$, isotopic $\mathrm{U}$, 
and Sr-90. If radiological field screening results do not exceed FSLs, then two samples (one from each sewage lagoon) will be selected by the Site Supervisor and submitted to the laboratory for gamma spectrometry.

\subsubsection{Contingency Sampling}

Contingency sampling may be conducted as Stage II of this field investigation and may include step-out sampling, use of a backhoe, or drilling using a hollow-stem auger or other appropriate drilling methods if contamination extends beyond the maximum investigation depth of the direct-push equipment. Borings will be advanced in approximately 5-ft intervals and will continue until field screening results for VOCs and radionuclides are below established field screening levels for two consecutive intervals.

\subsubsection{Field Screening}

Field screening for VOCs and radiation will be conducted at all sample locations. Background samples collected will be field screened for radionuclides only. Field screening for VOCs will utilize the headspace method (photoionization detector and waterbath). An Electra ${ }^{\mathrm{TM}}$ alpha/beta scintillator, a Sodium Iodide (NaI) detector, and possibly a gamma spectrometer (or equivalent) will be used to field screen for alpha/beta and gamma emitting radionuclides.

Field screening provides semiquantitative measurements of the soil conditions. These results will be used to guide the investigation and will also be used to aid in the selection of samples to be submitted for laboratory analysis.

\subsection{Background Samples}

Background surface and near-surface samples will be collected from two undisturbed locations within the vicinity of the lagoons and swale. These samples will be collected at approximately the 1-ft and 3-ft depths using the direct-push method, field-screened for radionuclides, and analyzed for radionuclides and total RCRA metals. The discrete background sample results will be compared to the investigation sample data results to evaluate the presence of radionuclides and RCRA metals above background concentrations at CAU 232. Background data collected at other Area 25 CAUs 
may be incorporated with this background data to evaluate and support corrective action alternatives at this site.

\subsection{Geotechnical Samples}

Samples may be collected at the discretion of the Site Supervisor and submitted for geotechnical analysis. Samples will not be shipped until radioanalytical results can be evaluated. Table 4-1 contains the parameters that will be considered for geotechnical analysis. The testing methods shown are minimum standards and other equivalent or superior testing methods may be used.

\section{Table 4-1 \\ General Geotechnical and Hydrological Analyses for CAU 232}

\begin{tabular}{|c|c|}
\hline Geotechnical Parameter & Methods \\
\hline Initial Moisture Content & ASTM $^{a}$ D 2216-92 \\
\hline Dry Bulk Density & ASTM $^{a}$ D 2937-94 \\
\hline Calculated Porosity & $\begin{array}{c}\mathrm{EM}^{\mathrm{b}} 1110-2-1906 \text { or } \mathrm{MOSA}^{\mathrm{c}} \\
\text { Chp. } 18\end{array}$ \\
\hline Water-Release (moisture retention) Curve & $\begin{array}{c}\text { MOSA }^{\mathrm{C}} \text { Chp. } 26 \\
\text { ASTM }^{\mathrm{a}} \text { D 2325-68(94) } \\
\text { MOSA }^{\mathrm{c}} \text { Chp. } 24 \\
\text { Karanthanasis and Hajek }\end{array}$ \\
\hline Particle Size Distribution & ASTM $^{a}$ D 422-63(90) \\
\hline Unsaturated Hydraulic Conductivity & van Genuchten $^{d}$ \\
\hline Saturated Hydraulic Conductivity & $\begin{array}{l}\text { ASTM }^{a} \text { D 2434-68(74) } \\
\text { MOSA }^{c} \text { Chp. } 28\end{array}$ \\
\hline
\end{tabular}

\footnotetext{
${ }^{\mathrm{a}}$ ASTM, 1996

bUSACE, 1970

${ }^{\mathrm{C}}$ MOSA (Soil Science Society of America, 1986)

dvan Genuchten, 1980

${ }^{\mathrm{e}}$ Karanthanasis and Hajek, 1982
}

\subsection{Quality Control Samples}

Quality control samples will be collected as required by the Industrial Sites QAPP (DOE/NV, 1996b) and other approved procedures. These samples will include trip blanks, equipment rinsate blanks, 
field blanks, field duplicates, and matrix spike/matrix spike duplicate (MS/MSD) samples. Except for trip blanks, all QC samples will be analyzed for all COPCs in Section 3.2. Trip blanks will only be analyzed for VOCs. Additional QC samples may be submitted at the discretion of the Site Supervisor.

\subsection{Sample Collection Procedures}

All samples, including QA/QC samples, will be collected in accordance with Standard Operating Procedures Manual (DOE/NV, 1994b) and the Industrial Sites QAPP (DOE/NV, 1996b). Records will be kept of the soil description, field screening measurements, and all other relevant data. All pertinent and required sampling information (i.e., date, time, sample interval) will be documented. All samples will be accompanied by the appropriate chain of custody documentation to ensure the integrity of the data.

\subsection{Decontamination Procedures}

Clean sampling equipment and containers will be used for each sampling event. All equipment which contacts the soil will be decontaminated prior to sampling and between samples in accordance with written and approved procedures consistent with the DOE/NV Environmental Restoration Division (ERD) Standard Operating Procedure ERD-05-701, "Sampling Equipment Decontamination" (DOE/NV, 1998a). This will minimize the potential for cross-contamination between sample locations.

\subsection{Documentation}

Records will be kept of the soil description, field screening measurements, and all other relevant data. Approved chain of custody procedures will be followed to assure data defensibility. Project records will be maintained according to the Industrial Sites QAPP (DOE/NV, 1996b), and written and approved procedures, plans, or instructions that meet the requirements of the ERD Standard Operating Procedures. 


\subsection{Waste Management}

Management of investigation-derived waste (IDW) will be based on regulatory requirements, field observations, process knowledge, and the results of laboratory analysis of the CAU 232 investigation samples. Decontamination activities will be performed according to approved contractor procedures specified in the contractor field sampling instructions and as appropriate for the COPCs identified for CAU 232.

Waste other than soil, such as disposable sampling equipment, PPE, and rinsate, is considered potentially contaminated waste only by virtue of contact with potentially contaminated media. Therefore, sampling and analysis of the IDW, separate from analyses of site investigation samples, may not be necessary. However, rinsate samples may be taken to support waste management activities. The data generated as a result of the site investigation and process knowledge will be used whenever possible to assign the appropriate waste type (i.e., sanitary, hazardous, low-level radioactive waste [LLW], or mixed) to the IDW.

No process knowledge has been identified that indicates that any release or disposal of any listed hazardous waste occurred. Therefore, if contaminants are identified, they will likely be characteristic rather than listed hazardous wastes.

If sanitary, hazardous, radioactive, and/or mixed waste are generated, it will be managed and disposed of in accordance with DOE Orders, U.S. Department of Transportation (DOT) regulations, RCRA regulations, NAC 459 (NAC, 1998b), and agreements and permits between the U.S. Department of Energy (DOE) and NDEP. There is no process knowledge indicating that hazardous or LLW waste was disposed of in the sewage lagoons. However, due to the nature of activities previously conducted in Area 25, IDW will be managed according to hazardous waste and LLW requirements until laboratory analyses are received and a final waste determination is made.

\subsection{Waste Minimization}

Corrective action investigation activities have been planned to minimize IDW generation.

Decontamination activities will only use as much water as necessary to decontaminate equipment and personnel to minimize the amount of rinsate generated. Waste, such as disposable sampling 
equipment, decontamination rinsate, and PPE will be segregated to the greatest extent possible to minimize the generation of hazardous, radioactive, and/or mixed waste.

\subsection{Potential Waste Streams}

Potentially contaminated waste generated during the investigation activities may include the following:

- Disposable sampling equipment (such as plastic, aluminum foil) and PPE

- Decontamination rinsate

- Soil

The waste will be managed as three waste streams. Waste will be traceable to its source and to individual samples; this information will be recorded in the waste management logbook.

\subsection{Investigation-Derived Waste Management}

Management requirements for sanitary, low-level radioactive, hydrocarbon, hazardous, and mixed waste are discussed further in the following sections. The IDW generated will be managed as potentially hazardous waste and potentially radioactive waste until laboratory results indicate either the presence or absence of RCRA regulated constituents, and/or radioactive constituents, respectively.

\subsubsection{Sanitary Waste}

Sanitary waste not directly associated with sampling activities typically consists of plastic, food, and paper products. This waste will be contained in plastic bags and will be transported to an approved solid waste management unit.

\subsubsection{Low-Level Radioactive Waste}

Radiological COPCs are not anticipated at CAU 232; however, due to the nature of Area 25, radiological controls, including the requirements detailed in this subsection, will be instituted and the IDW will be managed as LLW pending analysis. The waste will be stored in a Hazardous Waste Accumulation Area (HWAA)/Radioactive Controlled Area (RCA) or a HWAA/Radioactive Materials Area (RMA) until the waste is characterized and a waste determination is made based on 
analytical results and process knowledge. Waste will be managed in accordance with the contractor-specific waste certification program plan, DOE Orders (DOE, 1993), and the Nevada Test Site Waste Acceptance Criteria (NTSWAC) (DOE/NV, 1997b).

Drums used to contain soil shall be inspected prior to use. If a drum is damaged, cannot be locked, or cannot accommodate a tamper-indicating device (TID), it shall not be used. All drums will be locked or fitted with TIDs and labeled "Radioactive Material Pending Analysis." The drums will be staged at a designated RCA or RMA pending disposal. Selection of a RCA or RMA will be conducted by the ITLV Radiological Control Manager.

The PPE and disposable sampling equipment will be placed in clear plastic bags marked with the date and an associated sample location and/or sample number. The bags will be tagged with a contractor-specific waste tracking tag and logged in the contractor-specific waste management logbook.

Absorbent Stergo ${ }^{\mathrm{TM}}$ pads shall be added to drums of radiologically contaminated material. Contractor-specific waste tracking tags shall be used and may be attached to the inside liner, the exterior of the drums, or marked with the drum's unique identification number and stored with the contractor-specific logbook. The sample number must be placed on each tracking tag. Drum inspection and absorbent addition shall be documented on the appropriate form of the drum-specific waste certification file.

Rinsate may be analyzed separately to determine final disposition. If rinsate is categorized as low-level waste on the basis of container-specific sampling or other methods, it will be solidified prior to NTSWAC certification activities.

\subsubsection{Hydrocarbon}

The action level for soil contaminated with hydrocarbons is $100 \mathrm{mg} / \mathrm{kg}$ in the state of Nevada (NAC, 1998a). Soils and associated IDW with TPH levels above $100 \mathrm{mg} / \mathrm{kg}$ and containing RCRA-regulated constituents below regulatory limits shall be managed as hydrocarbon waste and shall be disposed of in accordance with all applicable regulations in a hydrocarbon landfill. 


\subsubsection{Hazardous Waste}

Suspected hazardous waste will be managed in accordance with RCRA and State of Nevada hazardous waste management regulations and interpreted as follows. Suspected hazardous waste will be placed in 55-gallon drums that meet DOT specifications in accordance with 49 Code of Federal Regulations (CFR) 172 (CFR, 1998k) which will be locked and fitted with TIDs. The IDW containers will comply with 40 CFR 265.1087 (CFR, 1998j), and drums shall be compatible with the waste in accordance with the requirements of 40 CFR 265.172 (CFR, 1998f). No incompatible wastes are expected to be generated; however, if incompatible waste is encountered in the field, it will be managed in accordance with 40 CFR 265.177 (CFR, 1998i) (i.e., shall not be placed in the same container and shall be separated so that in the event of a spill, leak, or release, incompatible wastes shall not contact one another). Drums shall be handled and inspected in accordance with the requirements of 40 CFR 265.173 and 174, respectively (CFR, 1998g and 1998h).

Hazardous waste shall be characterized in accordance with the requirements of 40 CFR 261 (CFR, 1998a). Characterization will be based on laboratory results and process knowledge. Drums containing IDW pending characterization will be marked with the words "Hazardous Waste Pending Analysis" until their regulatory status can be determined through interpretation and evaluation of laboratory results. The IDW shall be traceable to its source and associated samples. Traceability shall be maintained by assigning a unique waste tracking number to each container and by maintaining records including the waste management logbook that traces the IDW back to the samples. After receipt of analytical results and if hazardous waste is identified, it will be labeled and marked in accordance with the requirements of 40 CFR 262.31 and 40 CFR 262.32, respectively, (CFR, 1998c and 1998d) and State of Nevada requirements.

Hazardous waste, if identified, will be evaluated against the Nevada Test Site Performance Objectives for Certification of Nonradioactive Hazardous Waste (BN, 1995). A 90-day HWAA will be employed to temporarily accumulate IDW pending characterization and to ensure that the amount of waste being accumulated is compliant with applicable State of Nevada and federal requirements. Other methods, including waste packaging techniques outlined in Section 5.3.2, if necessary, shall be employed and shall be documented in the project-specific Field Activity Daily Log. 
Suspected hazardous waste will be accumulated as applicable at a HWAA at or near the site of generation for up to 90 days in accordance with 40 CFR 262.34 (CFR, 1998e). Prior to or on the ninetieth day of accumulation as specified in 40 CFR 262.34 (a) (CFR, 1998e), hazardous waste will be shipped by a licensed/permitted hazardous waste transporter to a permitted treatment storage, and disposal facility. If hazardous waste must remain on-site for longer than 90 days due to unforeseen, temporary, and uncontrollable circumstances, a letter requesting an extension for up to 30 days will be sent to the NDEP in accordance with 40 CFR Part 262.34 (CFR 1998e). A copy of the uniform hazardous waste manifest shall be provided to the State of Nevada.

\subsubsection{Mixed Waste}

Mixed waste is a combination of hazardous and radioactive waste. No mixed waste is expected to be generated at this site. However, if mixed waste is generated, the waste shall be managed in accordance with 40 CFR 262.11 (CFR, 1998b) and State of Nevada NAC 444 (NAC, 1997). These regulations, as well as DOE requirements for radioactive waste, are interpreted as follows. Where there is a conflict in regulations or requirements, the most stringent shall apply. For example, the 90-day accumulation time limit and weekly inspections per RCRA regulations will be applied to mixed waste even though it is not required for radioactive waste. Conversely, while RCRA does not require documented traceability, the NTSWAC for LLW does; therefore, traceability shall be documented.

In general, mixed waste shall be managed in the same manner as hazardous waste, with added mandatory radioactive waste management program requirements. Suspected mixed waste will be managed in accordance with applicable regulations and requirements and will be marked with the words "Hazardous Waste Pending Analysis" pending characterization and confirmation of its regulatory status. However, once the waste determination is made, or the RCRA 90-day time requirement draws to an end, mixed waste shall be transported via a permitted hazardous waste hauler to the NTS transuranic waste storage pad for storage pending treatment or disposal. Mixed waste with hazardous waste constituents below land disposal restrictions may be disposed of at the Area 5 Radioactive Waste Management Site. 
Mixed waste not meeting land disposal restrictions will require development of a treatment plan under the requirements of the Mutual Consent Order between DOE and the State of Nevada (NDEP, 1995). 


\subsection{Duration and Records Availability}

\subsection{Duration}

The following is a tentative schedule of activities (in calendar days) that will be initiated after the submittal of the Final CAIP for CAU 232 to NDEP (FFACO deadline of June 1, 1999):

- Day 0: Field work preparation begins.

- Day 30: Field work, including field screening and sampling begins.

- Day 40: Field work is complete and samples have been shipped to the laboratory for analyses.

- Day 150: The quality-assured laboratory analytical sample data is available for review.

- $\quad$ The FFACO deadline for the CADD is December 31, 1999.

\subsection{Records Availability}

This document is available in the DOE public reading rooms located in Las Vegas and Carson City, Nevada, or by contacting the DOE/NV Project Manager. The NDEP maintains the official Administrative Record for all activities conducted under the auspices of the FFACO. 


\subsection{References}

ASTM, see American Society for Testing and Materials.

American Society for Testing and Materials. 1996. Section 04.08 and 04.09, "Construction." Annual Book of ASTM Standards. Philadelphia, PA.

Atlan-Tech. 1992. Environmental Monitoring Report for the Proposed Ward Valley California Low-Level Radioactive Waste Facility. Rosewell, GA.

BN, see Bechtel Nevada.

Bechtel Nevada. 1995. Nevada Test Site Performance Objective for Certification of Nonradioactive Hazardous Waste, G-E11/96.01, Rev. 0. Las Vegas, NV.

Bechtel Nevada. 1996. Memorandum to D. Elle (DOE/NV) regarding quarterly discharge monitoring report for the Nevada Test Site sewage lagoons for October 1, 1995 through December 31, 1995, 04 January. Las Vegas, NV.

Bechtel Nevada. 1997. Memorandum to K.A. Hoar (DOE/NV) regarding the State public water system sanitary sewers compliance schedule, 11 February. Las Vegas, NV.

Bielawski. J. 1998. Record of telecon with L. Linden (SAIC) regarding Area 25 Sewage Lagoons, 28 December. Las Vegas, NV.

CFR, see Code of Federal Regulations.

Code of Federal Regulations. 1998a. 40 CFR Part 261, "Identification and Listing of Hazardous Waste.” Washington, DC: U.S. Government Printing Office.

Code of Federal Regulations. 1998b. 40 CFR Part 262.11, "Hazardous Waste Determination." Washington, DC: U.S. Government Printing Office.

Code of Federal Regulations. 1998c. 40 CFR Part 262.31, "Labeling." Washington, DC:

U.S. Government Printing Office.

Code of Federal Regulations. 1998d. 40 CFR Part 262.32, "Marking." Washington, DC:

U.S. Government Printing Office.

Code of Federal Regulations. 1998e. 40 CFR Part 262.34, “Accumulation Time.” Washington, DC: U.S. Government Printing Office. 
Code of Federal Regulations. 1998f. 40 CFR Part 265.172, "Compatibility of Waste with Container." Washington, DC: U.S. Government Printing Office.

Code of Federal Regulations. 1998g. 40 CFR Part 265.173, "Management of Containers." Washington, DC: U.S. Government Printing Office.

Code of Federal Regulations. 1998h. 40 CFR Part 265.174, "Inspections." Washington, DC: U.S. Government Printing Office.

Code of Federal Regulations. 1998i. 40 CFR Part 265.177, "Special Requirements for Incompatible Wastes." Washington, DC: U.S. Government Printing Office.

Code of Federal Regulations. 1998j. 40 CFR Part 265.1087, "Standards: Containers."

Washington, DC: U.S. Government Printing Office.

Code of Federal Regulations. 1998k. 49 CFR Part 172, "Hazardous Materials Table, Special Provisions, Hazardous Materials Communications, Emergency Response Information, and Training." Washington, DC: U.S. Government Printing Office.

DOE, see U.S. Department of Energy.

DOE/NV, see U.S. Department of Energy, Nevada Operations Office.

Edwards, D. (U.S. Geological Survey). 1998. Record of telecon with L. Linden (SAIC) regarding U.S. Geological Survey personnel occupying Test Cell 'C' Building 3229, 16 December. Las Vegas, NV.

EG\&G/EM, see EG\&G Energy Measurements.

EG\&G Energy Measurements. 1973. Aerial photo of TCC and Sewage Lagoons. Nellis Air Force Base, NV: RSL Photo Archive Library.

EPA, see U.S. Environmental Protection Agency.

FFACO, see Federal Facility Agreement and Consent Order.

Federal Facility Agreement and Consent Order. 1996 (as amended). Agreed to by the State of Nevada, the U.S. Department of Energy, and the U.S. Department of Defense. Las Vegas, NV.

Frazier, A.R. (Reynolds Electrical \& Engineering Company, Inc.) 1988. Letter to F. E. Bingham (DOE/NV) regarding the operations and maintenance plans of the Nevada Test Site - Area 25 sewage disposal systems, 15 June. Las Vegas, NV. 
Hale, G.S., and C.L. Westenburg. 1995. Selected Ground-Water Data for Yucca Mountain Region, Southern Nevada and Eastern California, Calendar Year 1993, USGS-Open-File Report 95-158. Carson City, NV: U.S. Geological Survey.

Hersh, S.D. (IT Corporation). 1998. Memorandum to File entitled "SDG 15720 Chemical Data Evaluation Summary," 21 January. Las Vegas, NV.

IT, see IT Corporation.

IT Corporation. 1997a. Ground-level photograph of the sewage lagoons facing northwest, number 250301p1, 05 March. Las Vegas, NV.

IT Corporation. 1997b. Ground-level photograph of the discharge pipe in east sewage lagoon, number 250301p2, 18 September. Las Vegas, NV.

IT Corporation. 1997c. Ground-level photograph of a stained outfall and remains of waste under discharge pipe in the west lagoon, number 250301p5, 18 September. Las Vegas, NV.

IT Corporation. 1999a. CAU 232, Area 25 sewage lagoons proposed sample locations, Nye County, Nevada. Composite of IT 1999d; RSL 1996 and 1973; and REECo 1966, 1968, and 1988. Las Vegas, NV.

IT Corporation. 1999b. Drawing of Area 25 Sewage Lagoons, CAS 25-03-01. Las Vegas, NV: Nevada Test Site.

IT Corporation. 1999c. Ground-level photograph of the Area 25 Sewage Lagoons swale, 07 January. Las Vegas, NV.

IT Corporation. 1999d. Ground-level survey results of Area 25 Sewage Lagoons. Las Vegas, NV.

IT Corporation. 1999e. Test Cell 'C' Facility Building Layout CAU 232, Area 25 Swage Lagoons, Nye County, Nevada. Composite of REECo 1963, 1966, 1968, 1984a, 1984b, and 1988; IT 1999d; and EG\&G/EM 1973. Las Vegas, NV.

Karanthanasis, A.D., and B.F. Hajek. 1982. "Quantitative Evaluation of Water Adsorption on Soil Clays.” In Soil Science Society of America Journal, 46: 1321-1325. Madison, WI.

McArthur, R.D., and F.L. Miller. 1989. Off-Site Radiation Exposure Review Project Phase II Soils Program, Water Resources Center Publication \#45064. Las Vegas, NV: Desert Research Institute, University of Nevada System.

Moore, E. (Bechtel Nevada). 1998. Record of telecon with L. Linden (SAIC) regarding Area 25 Sewage Lagoons, 08 December. Las Vegas, NV.

MOSA, see Soil Science Society of America. 
NAC, see Nevada Administrative Code.

NBMG, see Nevada Bureau of Mines and Geology.

Nevada Administrative Code. 1997. NAC 444.940 - NAC444.9555, "Sanitation." Carson City, NV: Nevada Division of Environmental Protection.

Nevada Administrative Code. 1998a. NAC 445A.2272, "Contamination of Soil: Establishment of Action Levels.” Carson City, NV: Nevada Division of Environmental Protection.

Nevada Administrative Code. 1998b. NAC 459.9973, 459.9975, and 459.9977, "Hazardous Material." Carson City, NV.

Nevada Bureau of Mines and Geology. 1998. Mineral and Energy Resource Assessment of the Nellis Air Force Range, Open-File Report 98-1. Reno, NV.

Nevada Division of Environmental Protection. 1995. Mutual Consent Agreement Between the State of Nevada and the U.S. Department of Energy for the Storage of Low-Level Land Disposal Restricted Mixed Waste, 6 June. Carson City, NV.

NRC, see U.S. Nuclear Regulatory Commission.

REECo, see Reynolds Electrical \& Engineering Company, Inc.

Remote Sensing Laboratory. 1996. Aerial photo number 8811-75 of TCC and Sewage Lagoons. Nellis Air Force Base, NV: Photo Archive Library.

Reynolds Electrical \& Engineering Company, Inc. 1963. Engineering drawing of NRDS Master Plan Detail Site Map of Test Cell 'C' Complex, number NRDS-SF-MA-6. Las Vegas, NV.

Reynolds Electrical \& Engineering Company, Inc. 1966. Engineering drawing of the Operations Building 3229, Test Cell 'C' Sewage Lagoon Plan and Details, number 3229-SP-5. Las Vegas, NV.

Reynolds Electrical \& Engineering Company, Inc. 1968. Engineering drawing of Operations Building 3229, Test Cell 'C' Sewer Line-Plan Profile, number 3 229-SP-7. Las Vegas, NV.

Reynolds Electrical \& Engineering Company, Inc. 1984a. Engineering drawings of existing water and sewer layout of Test Cell 'C' Plan, number 25-TC-C-C1. Las Vegas, NV.

Reynolds Electrical \& Engineering Company, Inc. 1984b. Engineering drawings of existing water and sewer layout of Test Cell 'C' Plans and Elevations, number 25-TC-C-C2. Las Vegas, NV.

Reynolds Electrical \& Engineering Company, Inc. 1988. Engineering drawing of the modifications to Test Cell ' $C$ ' and sewage facility, number 25-TC-C-C41. Las Vegas, NV. 
RSL, see Remote Sensing Laboratory.

Sanders, F.W. 1968. Decontamination of Test Cell 'C' at the Nuclear Rocket Development Station After a Reactor Accident, LA-3633-MS. Los Alamos, NM: Los Alamos National Laboratory.

Soil Science Society of America. 1986. Methods of Soil Analysis, 2nd Edition, part 1. Madison, WI.

USACE, see U.S. Army Corps of Engineers.

U.S. Army Corps of Engineers. 1970. "Laboratory Soils Testing.” In Engineering Manual 1110-2-1906, Appendix II. Washington, DC.

U.S. Department of Energy. 1993. DOE Order 5400.5, Radiation Protection of the Public and the Environment. Washington DC.

U.S. Department of Energy, Nevada Operations Office. 1984. Nevada Test Site, Area 25 Radiological Survey and Cleanup Project 1974-1983 CA Revised Final Report. Prepared by M.G. Miller. Las Vegas, NV: Reynolds Electrical \& Engineering Company, Inc.

U.S. Department of Energy, Nevada Operations Office. 1994a. Project Management Plan, Rev. 0. Las Vegas, NV.

U.S. Department of Energy, Nevada Operations Office. 1994b (as amended). Standard Operating Procedures Manual. Las Vegas, NV.

U.S. Department of Energy, Nevada Operations Office. 1996a. Final Environmental Impact Statement for the Nevada Test Site and Off-Site Locations in the State of Nevada, DOE/EIS 0243. Las Vegas, NV.

U.S. Department of Energy, Nevada Operations Office. 1996b. Industrial Sites Quality Assurance Project Plan, DOE/NV--372. Las Vegas, NV.

U.S. Department of Energy, Nevada Operations Office. 1997a. Integrated Safety Management Policy, DOE Order NV P 450.4. Las Vegas, NV.

U.S. Department of Energy, Nevada Operations Office. 1997b. Nevada Test Site Waste Acceptance Criteria, NTSWAC, Rev. 1. Las Vegas, NV.

U.S. Department of Energy, Nevada Operations Office. 1998a. Environmental Restoration Division (ERD) Standard Operating Procedure ERD-05-701, "Sampling Equipment Decontamination," Rev. 1. Las Vegas, NV.

U.S. Department of Energy, Nevada Operations Office. 1998b. Environmental Restoration Project Health and Safety Plan, Rev. 3. Las Vegas, NV. 
U.S. Environmental Protection Agency. 1994. Guidance for the Data Quality Objectives Process, EPA QA/G-4. Washington, DC.

U.S. Environmental Protection Agency. 1996. Test Methods for Evaluating Solid Waste, Physical/Chemical Methods, SW-846, Third Edition, CD ROM, PB97-501928GEI (CD-ROM includes revisions to 1986, 1992, and 1994). Washington, DC.

U.S. Environmental Protection Agency. 1998. Memorandum from S.J. Smucker to PRG table mailing list regarding Region IX Preliminary Remediation Goals, 1 August. San Francisco, CA.

van Drielen, H., Nevada Division of Environmental Protection. 1997. Letter to K. A. Hoar (DOE/NV) regarding revision of general Water Pollution Control Permit, 30 April. Las Vegas, NV.

van Genuchten, M. 1980. “A Closed Form Equation for Predicting the Hydraulic Conductivity of Unsaturated Soils.” In Soil Science Society of American Journal, 44: 892-898. Madison, WI. 


\section{Appendix A}

\section{Data Quality Objectives Worksheets}




\section{A.1.0 Introduction}

\section{A.1.1 Problem Statement}

Sanitary effluent was discharged from various buildings located within the TCC Facility into CAU 232, Area 25 Sewage Lagoons (CAS 25-23-01, Sewage Lagoon). The arsenic level in the west lagoon was detected slightly above the PRG during an earlier field sampling event. However, both the detected level and the PRG for arsenic are at or below the regional arsenic background concentrations for the NTS (NBMG, 1998). Existing information about the nature of contamination is insufficient to evaluate and select preferred corrective action for this site.

The CAU 232 investigation will be based on the DQOs developed by representatives of the NDEP and DOE/NV. This investigation will determine if COPCs are present in concentrations exceeding regulatory levels in the soils of the sewage lagoons and outfall swale. If COPCs are detected, the lateral and vertical extent of contamination will be delineated. Data adequate to close the site under State of Nevada regulations, RCRA, and DOE requirements will be collected.

\section{A.1.2 DQO Kickoff Meeting}

Table A.1-1 lists the participants present at the FFACO-required DQO Kickoff Meeting and any subsequent meetings. The goal of the DQO process is to establish the quantity and quality of environmental data required to support corrective action decisions for CAU 232. The process ensures that the information collected will provide sufficient and reliable information to identify, evaluate, and technically defend the chosen corrective action. Unless otherwise required by the results of this DQO and stated in the CAIP, this investigation will adhere to the Industrial Sites QAPP (DOE/NV, 1996b). 
Table A.1-1

DQO Kickoff Meeting Participants

\begin{tabular}{|l|l|c||}
\hline \multicolumn{1}{|c|}{ Participant } & \multirow{2}{*}{ Affiliation } & Meeting Date \\
\cline { 3 - 4 } & & $\begin{array}{c}\text { Kickoff Meeting } \\
1 / 19 / 99\end{array}$ \\
\hline \hline Jeanne Wightman & MACTEC & $\mathrm{X}$ \\
\hline Cheryl Rodriguez & IT & $\mathrm{X}$ \\
\hline Mark DiStefano & IT & $\mathrm{X}$ \\
\hline Syl Hersh & IT & $\mathrm{X}$ \\
\hline Linda Linden & SAIC & $\mathrm{X}$ \\
\hline Susan Zvoda & SAIC & $\mathrm{X}$ \\
\hline Don Cox & BN & $\mathrm{X}$ \\
\hline Matthew Truax & IT & $\mathrm{X}$ \\
\hline Mike Monahan & SAIC & $\mathrm{X}$ \\
\hline Steven Adams & IT & $\mathrm{X}$ \\
\hline Lydia Coleman & SAIC & $\mathrm{X}$ \\
\hline Sabine Curtis & DOE/NV & $\mathrm{X}$ \\
\hline Greg Raab & NDEP & $\mathrm{X}$ \\
\hline Dave Madsen & BN & $\mathrm{X}$ \\
\hline Janet Appenzeller-Wing & DOE/NV & \\
\hline \hline
\end{tabular}

BN - Bechtel Nevada

DOE/NV - U.S. Department of Energy, Nevada Operations Office

IT - IT Corporation

MACTEC - Management Analysis Company Technologies

NDEP - Nevada Division of Environmental Protection

SAIC - Science Applications International Corporation 


\section{A.2.0 Conceptual Model}

The CAU 232, Area 25 Sewage Lagoons, consists of two parallel lagoons and an outfall swale that were used to receive sanitary effluent from four buildings at the TCC Facility in Area 25 of the NTS, Nevada. Area 25 was historically used to develop nuclear propulsion technology using test reactor studies conducted from the mid-1960s to around 1973. The sewage lagoons are located $0.3 \mathrm{mi}$ south of TCC. The approximate outside dimensions for the west and east sewage lagoons are $100 \times 60 \mathrm{ft}$ and $100 \times 50 \mathrm{ft}$, respectively; each lagoon reaches a depth of about $5 \mathrm{ft}$ (IT, 1999). The outfall swale is located $500 \mathrm{ft}$ southwest of the lagoons. The sewage lagoons were operational from about 1966 to 1988 and then modified in the early 1990s (REECo, 1988). After modification, the sewage lagoons were put back in service from 1992 to 1996. Three to four U.S Geological Survey staff members occupied the Operations Building (Building 3229) at TCC during this time (Edwards, 1998). Section 2.0 of the CAIP provides additional information regarding the site, such as the operational history, waste inventories, release information, and investigative backgrounds.

The conceptual model for CAU 232 is provided in Table A.2-1. 
Table A.2-1

Conceptual Model For CAU 232, Area 25 Sewage Lagoons (Page 1 of 4 )

\begin{tabular}{|c|c|c|}
\hline $\begin{array}{c}\text { Conceptual Model } \\
\text { Element }\end{array}$ & Descriptions/Assumptions & Source \\
\hline & $\begin{array}{l}\text { The CAU } 232 \text { consists of two sewage lagoons and one outfall } \\
\text { swale. The lagoons are located south of the TCC Facility in } \\
\text { Area } 25 \text { of the NTS. The swale is located approximately } \\
500 \mathrm{ft} \text { southwest of the lagoons. } \\
\text { The TCC facility was used for nuclear propulsion studies } \\
\text { using test reactors that emitted, at a minimum, a radioactive } \\
\text { hydrogen gas exhaust. } \\
\text { The lagoons received sanitary effluent from four buildings. } \\
\text { Piping leads from TCC to a diverter box and then to the } \\
\text { lagoons. It is uncertain if the sewage lagoons were used in } \\
\text { series or in parallel and if the outfall swale was only used at } \\
\text { those times when both lagoons were filled to capacity. }\end{array}$ & $\begin{array}{l}\text { Engineering drawings } \\
\text { (REECo, 1966, 1984, } \\
\text { and 1988) } \\
\text { Process knowledge } \\
\text { EG\&G/EM, } 1973\end{array}$ \\
\hline System Dynamics & $\begin{array}{l}\text { TCC History: } \\
\text { Previous existence of fission by-products along with the use } \\
\text { of hazardous materials for TCC operations. } \\
\text { A variety of tanks and buildings were involved in supplying } \\
\text { fluids to the reactors and in housing electronic controls. } \\
\text { Phoebus IA reactor accident occurred on } 6 / 25 / 65 \\
\text { contaminating approximately } 5 \text { acres with } 8 \text { to } 15 \text { percent of } \\
\text { the core from the reactor. } \\
\text { KIWI Transient Nuclear Test was conducted within the area } \\
\text { of TCC in the } 1960 \text { s. The test involved a controlled explosion } \\
\text { of a reactor. The extent of contamination is unknown. } \\
\text { Decontamination of TCC and surrounding area was } \\
\text { performed from } 1965 \text { through } 1983 \text {. It is unclear if the } \\
\text { sewage lagoons were included in radiological surveys. } \\
\text { Decontamination processes may have contaminated TCC } \\
\text { (e.g., oil bath filter used by cyclone separator and the oils } \\
\text { sprayed on the radioactive soil stockpiles.) It is unknown if } \\
\text { the oils used were petroleum hydrocarbon derivatives. } \\
\text { Note: It is anticipated that the above mentioned events did } \\
\text { not have a significant impact on the sewage lagoons; } \\
\text { therefore, radionuclides in excess of background } \\
\text { concentrations are not anticipated. }\end{array}$ & $\begin{array}{l}\text { LOE/NV, } 1984 \\
\text { LANL, 1965a } \\
\text { LANL, 1965b } \\
\text { LANL, } 1968 \\
\text { Process knowledge } \\
\text { Sanders, } 1968 \\
\text { DOE/NV, } 1984\end{array}$ \\
\hline
\end{tabular}


Table A.2-1

Conceptual Model For CAU 232, Area 25 Sewage Lagoons

(Page 2 of 4 )

\begin{tabular}{|c|c|c|}
\hline $\begin{array}{c}\text { Conceptual Model } \\
\text { Element }\end{array}$ & Descriptions/Assumptions & Source \\
\hline \multirow[b]{2}{*}{ Source Locations } & $\begin{array}{l}\text { The sewage lagoon(s) received } 29,000 \text { gallons of liquid from } \\
\text { Area } 25 \text { Reactor Control Point sewage lagoons over a two } \\
\text { month period in } 1995 \text {. Constituents of the liquid received } \\
\text { from the Area } 25 \text { Reactor Control Point are unknown, but } \\
\text { action levels required by the Water Pollution Control Permit } \\
\text { were not exceeded. It is uncertain which lagoon was filled or } \\
\text { if both lagoons and the outfall swale were used. } \\
\text { Sewage Lagoons removed from Water Pollution Control } \\
\text { Permit in } 1997 .\end{array}$ & $\begin{array}{l}\text { Correspondence from } \\
\text { Bechtel to DOE } \\
\text { (BN, 1996) } \\
\text { van Drielen, } 1997 \\
\text { Process Knowledge }\end{array}$ \\
\hline & $\begin{array}{l}\text { Usage volumes are unknown. } \\
\text { TCC Building } 3229 \text { served as office space. } \\
\text { Building } 3220 \text { served as a pump house and equipment } \\
\text { building. Unclear if floor drains in this building led to the } \\
\text { sewage lagoons. } \\
\text { Use of the former RADSAFE check station trailer is unknown. } \\
\text { Building } 3224 \text { served as a restroom. } \\
\text { Assume worst case to be located within lagoons. } \\
\text { Assume COPCs to be concentrated at outfall and ponding } \\
\text { locations within lagoons. }\end{array}$ & $\begin{array}{l}\text { Edwards, } 1998 \\
\text { Engineering drawings } \\
\text { (REECo, 1984) } \\
\text { REECO, 1966; 1984; } \\
\text { and 1988 } \\
\text { Process Knowledge }\end{array}$ \\
\hline $\begin{array}{c}\text { Evidence for } \\
\text { Contaminants of } \\
\text { Potential Concern }\end{array}$ & $\begin{array}{l}\text { Pesticides, herbicides, algaecide, and rodenticides reportedly } \\
\text { used at sewage lagoons on the NTS. } \\
\text { The } 1973 \text { aerial photo shows liquid in the west lagoon. } \\
\text { The } 1997 \text { land photo shows the west lagoon containing solid } \\
\text { waste, presumed to be solid sanitary effluent and paper } \\
\text { products. }\end{array}$ & $\begin{array}{l}\text { E. Moore, } 1998 \\
\text { Morgan, } 1998 \\
\text { Bielawski, } 1998 \\
\text { Process knowledge } \\
\text { IT, } 1997 \\
\text { EG\&G/EM, } 1973 \\
\text { Frazier, } 1988 \\
\text { Process knowledge }\end{array}$ \\
\hline
\end{tabular}


Table A.2-1

Conceptual Model For CAU 232, Area 25 Sewage Lagoons (Page 3 of 4 )

\begin{tabular}{|c|c|c|}
\hline $\begin{array}{l}\text { Conceptual Model } \\
\text { Element }\end{array}$ & Descriptions/Assumptions & Source \\
\hline & $\begin{array}{l}\text { Preliminary assessment sample results indicate presence of } \\
\text { total VOCs, total SVOCs, total pesticides, and total RCRA } \\
\text { metals. Radionuclides concentrations are within background } \\
\text { concentrations. } \\
\text { All but the RCRA metal arsenic are below PRG } \\
\text { concentrations. The detected arsenic concentration exceeds } \\
\text { the PRG level, but remains within NTS background } \\
\text { concentrations. }\end{array}$ & $\begin{array}{l}\text { Hersh, } 1998 \\
\text { J. Moore, } 1999 \\
\text { Adams, } 1999\end{array}$ \\
\hline $\begin{array}{l}\text { Physical and practical } \\
\text { constraints }\end{array}$ & $\begin{array}{l}\text { Berms around lagoons and location of swale; heavy } \\
\text { equipment and resource availability; health and safety } \\
\text { concerns; and approval of the CAIP. }\end{array}$ & Process knowledge \\
\hline $\begin{array}{l}\text { Lateral extent of } \\
\text { potential } \\
\text { contaminants }\end{array}$ & $\begin{array}{l}\text { Extent of contamination in the swale, if any, is unknown. } \\
\text { Potential for down-gradient migration at the swale. } \\
\text { Lateral extent of contamination, if any, is confined within the } \\
\text { original and modified lagoons where a homogenous } \\
\text { distribution of the liquid contents is most probable. }\end{array}$ & Process knowledge \\
\hline $\begin{array}{l}\text { Vertical extent of } \\
\text { potential } \\
\text { contaminants }\end{array}$ & $\begin{array}{l}\text { The vertical extent of potential contamination is unknown, but } \\
\text { if present, will likely be concentrated underneath the lagoons } \\
\text { and below the outfall location at the swale. } \\
\text { Vertical extent of contamination, if any, is likely not to extend } \\
\text { beyond } 3 \mathrm{ft} \text {, possibly as a result of bioplugging. } \\
\text { Groundwater contamination is not a concern at this site since } \\
\text { vertical extent should be limited by low contaminant } \\
\text { concentrations and volumes, lack of driving force and } \\
\text { relatively low mobility of COPCs. } \\
\text { Groundwater impacts are not anticipated due to the depth to } \\
\text { groundwater. Well J-11 is located at approximately } 3.0 \mathrm{mi} \\
\text { south of TCC. The depth to groundwater at this well is } \\
\text { approximately } 1,000 \mathrm{ft} \text { bgs. Wells } \mathrm{J}-12 \text { and J-13, farther } \\
\text { away, derive their water from an aquifer approximately } 820 \mathrm{ft} \\
\text { bgs. }\end{array}$ & $\begin{array}{l}\text { Process knowledge } \\
\text { Hale and Westenberg, } \\
1995\end{array}$ \\
\hline Future use of the site & $\begin{array}{l}\text { Similar to current industrial, administrative, and research } \\
\text { related activities. }\end{array}$ & $\mathrm{DOE} / \mathrm{NV}, 1996 \mathrm{a}$ \\
\hline Potential exposures & $\begin{array}{l}\text { Oral ingestion, inhalation, or dermal contact (absorption) of } \\
\text { COPCs due to inadvertent exposure during sampling } \\
\text { activities. }\end{array}$ & Process Knowledge \\
\hline
\end{tabular}




\section{Table A.2-1}

Conceptual Model For CAU 232, Area 25 Sewage Lagoons

(Page 4 of 4 )

\begin{tabular}{|c|l|c||}
\hline $\begin{array}{c}\text { Conceptual Model } \\
\text { Element }\end{array}$ & \multicolumn{1}{|c|}{ Descriptions/Assumptions } & Source \\
\hline \hline Waste Management & $\begin{array}{l}\text { No evidence of RCRA listed waste has been found; waste will } \\
\text { be considered RCRA characteristic if identified in laboratory } \\
\text { analysis, unless contrary information is discovered during the } \\
\text { investigation. }\end{array}$ & Process Knowledge \\
\hline
\end{tabular}




\section{A.3.0 Potential Contaminants}

Section 3.0 of the CAIP provides additional information on the COPCs for CAU 232, including PALs and QA/QC requirements.

Previous sampling results and process knowledge identify the following COPCs for CAU 232:

- VOCs, SVOCs, RCRA metals, petroleum hydrocarbons, PCBs, pesticides, herbicides, gamma emitters, isotopic $\mathrm{Pu}$, isotopic $\mathrm{U}$, and $\mathrm{Sr}-90$ based upon:

- Arsenic which was detected at $3.1 \mathrm{mg} / \mathrm{kg}$ is above the PRG level of $3.0 \mathrm{mg} / \mathrm{kg}$, but is within background concentrations for the NTS.

- Potential contamination associated with sewage lagoon operations (e.g., pesticides, rodenticides, herbicides, algaecide).

- Potential for contaminated sanitary effluent being discharged from the various source buildings within the TCC Facility (i.e., RADSAFE Check Point Trailer, Pump House). Lack of information regarding specific operations performed at the buildings.

- Potential contaminants associated with the operations and decontamination of a nuclear testing facility. Housekeeping practices, storage of materials, and disposal of waste for this purpose is unknown.

- Potential for contamination from the transfer of fluid from the Area 25 Reactor Control Point sewage lagoon(s) to CAU 232 in 1995.

- Consideration of the nuclear rocket testing events conducted at TCC in addition to the reactor incident at TCC in 1965. Note: It is anticipated that these events did not have a significant impact on the sewage lagoons; therefore, radionuclides in excess of the background concentrations are not anticipated. 
The presence of contaminants will be evaluated through both field screening and laboratory analyses. Samples submitted for laboratory analysis (as defined in Table A.3-1) will be analyzed according to the requirements in Appendix $\mathrm{C}$ for the following COPCs:

- Total VOCs

- Total SVOCs

- $\mathrm{PCBs}$

- Total pesticides

- Total herbicides

- Total RCRA metals

- $\quad$ TPH - (gasoline- and diesel-range organics)

- Radionuclides - If elevated gamma spectrometry results are obtained in the field, then laboratory analysis for isotopic $\mathrm{Pu}$, isotopic $\mathrm{U}$, and $\mathrm{Sr}-90$ will be performed. If field screening equipment other than gamma spectrometry is used and results are above the field screening levels, then laboratory analysis will include gamma spectrometry, isotopic $\mathrm{Pu}$, isotopic $\mathrm{U}$, and $\mathrm{Sr}-90$. If field screening results do not exceed FSLs, then two samples (one from each lagoon) will be selected by the Site Supervisor and submitted to the laboratory for gamma spectrometry.

Background samples will only be analyzed for radionuclides and total RCRA metals. 
Table A.3-1

Contaminants of Potential Concern

\begin{tabular}{|c|c|c|c|c|}
\hline Potential & Comments & $\begin{array}{l}\text { Field Screening } \\
\text { Methods }\end{array}$ & $\begin{array}{l}\text { Field Screening } \\
\text { Level }\end{array}$ & Preliminary Remediation Goals \\
\hline Total VOCs & $\begin{array}{l}\text { Not expected; however, 2-butanone, acetone, } \\
\text { toluene, trichloroethene, xylenes, methylene } \\
\text { chloride were detected in preliminary samples, } \\
\text { but below PALs. }\end{array}$ & Headspace & $\begin{array}{l}20 \text { ppm or } 2.5 X \\
\text { background (use } \\
\text { greater value) }\end{array}$ & $\begin{array}{c}\text { PRGs }{ }^{\mathrm{a}} \\
\mathrm{NAC} 445^{\mathrm{b}}\end{array}$ \\
\hline Total SVOCs & $\begin{array}{l}\text { Not expected; however, di-n-octylphthalate, bis(2- } \\
\text { ethylhexyl)phthalate were detected in preliminary } \\
\text { samples, but below PALs. }\end{array}$ & NA & NA & $\begin{array}{c}\text { PRGs }^{\mathrm{a}} \\
\text { NAC } 445 \mathrm{~A}^{\mathrm{b}}\end{array}$ \\
\hline Total RCRA Metals & $\begin{array}{l}\text { Barium, chromium, lead, and mercury were } \\
\text { detected in preliminary samples, but are below } \\
\text { PALs and within background concentrations. } \\
\text { Arsenic was detected to be slightly elevated } \\
(3.1 \mathrm{mg} / \mathrm{kg} \text { ) above the PRG ( } 3.0 \mathrm{mg} / \mathrm{kg} \text { ) but is } \\
\text { within background concentrations. }\end{array}$ & NA & NA & $\begin{array}{c}\text { PRGs }{ }^{a} \\
\text { NAC } 445 A^{b}\end{array}$ \\
\hline $\begin{array}{l}\text { Total Pesticides, } \\
\text { Total Herbicides and } \\
\text { PCBs }\end{array}$ & $\begin{array}{l}\text { Expected because they may have been used to } \\
\text { control, rodents, insects, and weeds. } 4,4^{\prime} \text {-DDT } \\
\text { and endosulfan sulfate were detected in } \\
\text { preliminary samples, but below PALs. }\end{array}$ & NA & NA & $\begin{array}{c}\text { PRGs }{ }^{a} \\
\text { NAC } 445 A^{b}\end{array}$ \\
\hline $\begin{array}{l}\text { TPH (gasoline- and } \\
\text { diesel-range } \\
\text { organic) }\end{array}$ & $\begin{array}{l}\text { Not expected, but TCC building usage is } \\
\text { unknown. }\end{array}$ & NA & NA & $\begin{array}{c}100 \text { ppm } \\
\text { NAC } 445 A^{b}\end{array}$ \\
\hline Radionuclides & $\begin{array}{l}\text { Gross alpha, gross beta, lead } 212 \text { and } 214 \text {, } \\
\text { thallium-208, and potassium- } 40 \text { were detected in } \\
\text { preliminary samples, but are within background } \\
\text { concentrations. }\end{array}$ & $\begin{array}{l}\text { Electra }{ }^{\mathrm{TM}} \text { Alpha/Beta, } \\
\text { Nal detector and } \\
\text { possibly gamma } \\
\text { spectrometry }\end{array}$ & $\begin{array}{l}\text { Mean background } \\
\text { activity plus } 2 x \\
\text { standard deviations } \\
\text { for } 20 \text { background } \\
\text { sample readings }^{c}\end{array}$ & $\begin{array}{l}\text { The PAL is the radionuclide } \\
\text { concentration that is exceeded in } \\
\text { environmental samples taken from } \\
\text { undisturbed background locations. }\end{array}$ \\
\hline
\end{tabular}

a EPA Region IX Preliminary Remediation Goals (PRGs) (EPA, 1998)

“Adams, S.R. 1998. Memo to D. Arnold regarding "Daily Response Check of Fidler at the Double Tracks RADSAFE Area," 16 June. Las Vegas, NV: IT Corporation.

NA $=$ Not Applicable 


\section{A.4.0 Decisions and Inputs}

\section{A.4.1 Decisions}

Decisions to be resolved by the investigation include:

- Determine the presence or absence of COPCs.

- If COPCs are present, determine whether COPC concentrations exceed field screening levels.

- If COPCs exceed field screening levels, determine whether COPC concentrations exceed PALs.

- If COPCs exceed PALs, determine the nature and extent of contamination with enough certainty to develop and evaluate a range of potential corrective actions, including closure in place and clean closure.

\section{A.4.2 Inputs and Strategy}

Inputs are those elements of information used to support the decisions in addressing the identified problem. The strategy provides either the rational to support the decision or the methodology for collecting data to arrive at the decision. A list of information inputs, existing data, data gaps, and brief strategies are discussed in Table A.4-1. 
Table A.4-1

Decisions, Inputs, and General Strategies

(Page 1 of 3 )

\begin{tabular}{|c|c|c|c|c|}
\hline Decision & Input & Existing Data & Data Gap & Strategy \\
\hline \multirow[b]{3}{*}{$\begin{array}{l}\text { Are COPCs present above } \\
\text { PALs at site? }\end{array}$} & Potential contaminant identification & Existing sample data from 1997. & Exact COPCs, if any. & $\begin{array}{l}\text { Collect soil samples from biased locations; } \\
\text { analyze for COPCs. }\end{array}$ \\
\hline & $\begin{array}{l}\text { Potential contaminant } \\
\text { concentration }\end{array}$ & $\begin{array}{l}\text { Existing sampling data } \\
\text { from } 1997 .\end{array}$ & $\begin{array}{l}\text { Identity of COPCs and } \\
\text { concentrations. } \\
\text { Unsampled swale; do } \\
\text { concentration exceed PALs? }\end{array}$ & \multirow{2}{*}{$\begin{array}{l}\text { Collect soil samples from biased locations } \\
\text { that represent worst-case scenarios. Field } \\
\text { screening results will be compared to } \\
\text { FSLs and laboratory results will be } \\
\text { compared to PALs. } \\
\text { Sample collection may be extended if } \\
\text { COPCs are above FSLs. Submit soil } \\
\text { sample for analysis from interval with the } \\
\text { highest field screening result and the } \\
\text { bottom two consecutive samples that have } \\
\text { field screening results below field } \\
\text { screening levels. Stepout locations may } \\
\text { be added. Backhoe use or drilling may be } \\
\text { implemented as necessary as a Stage II } \\
\text { investigation. } \\
\text { Background samples will be collected and } \\
\text { submitted for analysis for total RCRA } \\
\text { metals and radionuclides. }\end{array}$} \\
\hline & Potential contaminant distribution & $\begin{array}{l}\text { Location of the sewage lagoons is } \\
\text { known. } \\
\text { Homogenous spread of liquid } \\
\text { within lagoon. } \\
\text { The vertical and lateral extent of } \\
\text { COPCs is assumed to be limited to } \\
\text { footprint of lagoons and beneath } \\
\text { the pipe in the outfall swale. } \\
\text { Vertical and lateral extent limited by } \\
\text { removal of driving force. } \\
\text { Limited by geological, operational, } \\
\text { and meteorological characteristics. }\end{array}$ & $\begin{array}{l}\text { Vertical and lateral extent of } \\
\text { COPCs within the lagoons and the } \\
\text { outfall swale. } \\
\text { Identify vertical and lateral extent of } \\
\text { COPCs. }\end{array}$ & \\
\hline
\end{tabular}


Table A.4-1

Decisions, Inputs, and General Strategies

(Page 2 of 3 )

\begin{tabular}{|c|c|c|c|c|}
\hline Decision & Input & Existing Data & Data Gap & Strategy \\
\hline \multirow[b]{3}{*}{$\begin{array}{l}\text { Are potential } \\
\text { contaminants migrating? }\end{array}$} & Meteorologic data & $\begin{array}{l}\text { The NTS and Yucca Mountain Site } \\
\text { Characterization Project data on } \\
\text { annual precipitation, } \\
\text { evapotranspiration (Meyers and } \\
\text { Nordenson, 1962), and weather. }\end{array}$ & $\begin{array}{l}\text { None. Sufficient information } \\
\text { available. }\end{array}$ & $\begin{array}{l}\text { No site-specific meteorological data will be } \\
\text { collected; general weather conditions are } \\
\text { noted on daily field notes. }\end{array}$ \\
\hline & Geologic/hydrologic data & $\begin{array}{l}\text { General geologic/hydrologic } \\
\text { characteristics of the site } \\
\text { (Laczniak et al., 1996). } \\
\text { Specific geologic conditions of } \\
\text { nearby sites (Wahl et al., 1997). }\end{array}$ & $\begin{array}{l}\text { Existence and characteristics of } \\
\text { differing permeability zones. }\end{array}$ & $\begin{array}{l}\text { Samples may be collected from the } \\
\text { lagoons for geotechnical analysis. } \\
\text { Assume mainly near-surface investigation. } \\
\text { General soil characteristics will be noted } \\
\text { on sample collection log. }\end{array}$ \\
\hline & Radiological data & $\begin{array}{l}\text { Possibility that radionuclide } \\
\text { contamination exists as the result } \\
\text { of the reactor accident in } 1965 \\
\text { (Sanders,1968) and/or from } \\
\text { RADSAFE Check Point trailer } \\
\text { operations. } \\
\text { Possible radionuclide } \\
\text { contamination from KIWI Transient } \\
\text { Nuclear Test (LANL, 1965a) }\end{array}$ & $\begin{array}{l}\text { None anticipated, but will conduct } \\
\text { precautionary field screening for } \\
\text { radionuclides. } \\
\text { Need additional background } \\
\text { samples. }\end{array}$ & $\begin{array}{l}\text { Establish field screening levels for alpha/ } \\
\text { beta and gamma radiation using Electra }{ }^{\mathrm{TM}} \\
\text { and Nal instruments or equivalents. } \\
\text { Possibly use gamma spectrometry in the } \\
\text { field. } \\
\text { If elevated gamma spectrometry results } \\
\text { are obtained in the field, isotopic Pu, } \\
\text { isotopic U, and Sr-90 will be run. If other } \\
\text { equipment is used and results are above } \\
\text { field screening levels then laboratory } \\
\text { analysis will include gamma spectrometry, } \\
\text { in addition to isotopic Pu, isotopic U, and } \\
\text { Sr-90. } \\
\text { If radiological field screening results do not } \\
\text { exceed FSLs, then two samples (one from } \\
\text { each lagoon) will be selected by the Site } \\
\text { Supervisor and submitted to the laboratory } \\
\text { for gamma spectrometry. } \\
\text { If the vertical depth of the contamination } \\
\text { cannot be established at the sewage } \\
\text { lagoons or swale, sampling activities may } \\
\text { be continued as a Stage II activity. } \\
\text { Background samples will be collected and } \\
\text { submitted for radioanalysis. }\end{array}$ \\
\hline
\end{tabular}


Table A.4-1

Decisions, Inputs, and General Strategies

(Page 3 of 3 )

\begin{tabular}{|c|c|c|c|c|}
\hline Decision & Input & Existing Data & Data Gap & Strategy \\
\hline \multirow{3}{*}{$\begin{array}{l}\text { Data sufficient to support } \\
\text { closure options? }\end{array}$} & No further action & $\begin{array}{l}\text { There is no historical evidence of } \\
\text { COPCs being released to the } \\
\text { environment. However, there is not } \\
\text { enough information about the } \\
\text { buildings serviced by the sewage } \\
\text { lagoons or the Area } 25 \text { Control } \\
\text { Reactor Point liquid that was added } \\
\text { to the lagoons to recommend no } \\
\text { further action (BN, 1996). }\end{array}$ & $\begin{array}{l}\text { Presence, concentration, and } \\
\text { extent of COPCs. }\end{array}$ & $\begin{array}{l}\text { Collect field and laboratory samples and } \\
\text { compare results to FSLs and PALs, } \\
\text { respectively. If no COPCs are above } \\
\text { PALs, prepare CADD/Closure Report }\end{array}$ \\
\hline & Closure in place & $\begin{array}{l}\text { Assume industrial soil PRG per } \\
\text { NAC 445A (NAC, 1998); assume } \\
100 \text { ppm for TPH per NAC 445A; } \\
\text { assume radionuclide } \\
\text { concentrations are in the range of } \\
\text { background concentrations; } \\
\text { assume use restrictions with signs } \\
\text { as needed. }\end{array}$ & $\begin{array}{l}\text { Presence of regulated COPCs. } \\
\text { Concentrations above PALs. }\end{array}$ & \multirow[t]{2}{*}{$\begin{array}{l}\text { Collect field and laboratory samples and } \\
\text { compare results to FSLs and PALs, } \\
\text { respectively. If no COPCs are above } \\
\text { PALs, prepare CADD/Closure Report; } \\
\text { otherwise prepare CADD. }\end{array}$} \\
\hline & $\begin{array}{l}\text { Clean closure by contaminant } \\
\text { removal }\end{array}$ & $\begin{array}{l}\text { Assume industrial soil PRGs per } \\
\text { NAC 445A (NAC, 1998); assume } \\
100 \text { ppm for TPH per NAC 445A; } \\
\text { radionuclide concentrations are in } \\
\text { the range of background } \\
\text { concentrations. }\end{array}$ & $\begin{array}{l}\text { Presence, concentration, and } \\
\text { extent of COPCs. } \\
\text { Volume of contaminated material } \\
\text { above PALs. }\end{array}$ & \\
\hline
\end{tabular}

PRGs - Preliminary Remediation Goal(s)

NAC - Nevada Administrative Code

ppm - Part(s) per million

PALs - Preliminary Action Level(s)

CADD - Corrective Action Decision Document 


\section{A.5.0 Investigation Strategy}

Biased surface and near surface soil sampling will be conducted during the field investigation to determine the presence and the extent of COPCs and whether concentrations exceed PALs for the site.

The primary investigation techniques will be direct-push sample collection using the Geoprobe ${ }^{\circledR}$. A total of six direct-push locations will be investigated within the lagoons (three per lagoon). One direct-push location will be placed at the outfall swale. Two direct-push locations will be placed in undisturbed areas near the site for background sample collection. A minimum of 14 samples will be collected for investigation, four samples for background analysis, and a minimum of five QA/QC samples. Samples will be collected at approximately 1-ft and 3-ft depths at each location. Sample collection may be extended to approximately 5-ft and 8-ft depths, if field screening results exceed FSLs. Samples with highest field screening result above field screening action levels will be submitted for analysis along with the bottom two consecutive samples that have field screening results below field screening action levels.

The use of a backhoe or drilling may be required depending on the extent of potential contamination. If drilling is required, it will be conducted in a Stage II of the investigation based on field observations and/or laboratory analysis of samples generated by the initial stage of the investigation.

The investigation of the CAU 232 will be as follows:

- $\quad$ Geoprobe ${ }^{\circledR}$ will be used to collect biased surface and near-surface soil samples for field screening and laboratory analyses.

- Biased sample locations will be placed at each of the three outfall locations within the lagoons (one in the west lagoon, two in the east lagoon), two locations in the west lagoon where ponding may have occurred, two at undisturbed background locations, and one at the outfall swale. Even though an overlap exists between the existing lagoon and the original lagoon footprints, samples will be placed to represent a worst-case scenario for both. 
- An additional random sample will be placed in the east lagoon.

- Additional soil sampling (i.e., deeper or step-out) may be directed at the discretion of the Site Supervisor based on field screening and visual observations.

- Geotechnical samples may be collected from the sewage lagoons as identified by the investigation plan provided in Section 4.3 of the CAIP. The sample location(s) will be selected at the discretion of the Site Supervisor. The samples will not be shipped until radioanalytical results can be evaluated.

- QC samples will be collected.

- Samples will be field-screened for:

- VOCs using the headspace method.

- Radioactivity using an Electra ${ }^{\mathrm{TM}}$ alpha/beta scintillator, a NaI detector, and possibly a gamma spectrometer, or equivalents.

- COPCs identified in Section 3.0 of the CAIP will be analyzed in accordance with the requirements in Appendix C. 


\section{A.6.0 Decision Rules}

The following decision rules are applicable to this CAU 232 investigation and will be used to guide the investigation and subsequent data evaluation:

- If, in the course of the investigation, the conceptual model fails to such a degree that rescoping is required, then the investigation will be halted and rescoped as necessary.

- Field Screening and Sampling:

- If field screening results of the samples collected at approximately the 1-ft depth indicate that no COPCs are present above field screening levels, then another sample will be collected at approximately $3 \mathrm{ft}$, field screened, and if below field screening levels, submitted with the previous sample for analysis.

- If field screening results of the sample collected at approximately the 1-ft depth indicate that COPCs are present above field screening levels, then samples at approximately 3 - $\mathrm{ft}$ and 5 -ft depths will be collected. If field screening results remain elevated, a sample will be collected at approximately $8 \mathrm{ft}$. The sample(s) (representative of each sample collecting location) with the highest field screening results will be submitted for laboratory analyses along with the two consecutive samples that have results less than field screening levels. The COPCs discussed in Section 3.0 of the CAIP will be analyzed in accordance with the requirements in Appendix C.

- Step-out sampling may be conducted at the swale if field screening results indicate contamination. This will be done by the direct-push method.

- If the vertical depth of the contamination cannot be established at the sewage lagoons or swale using the Geoprobe ${ }^{\circledR}$, sampling activities may be continued using a backhoe or drilling method as a Stage II activity.

- If analytical results are not adequate for preparation of a CADD, additional step-out sampling using the direct-push method, backhoe, or drilling may be conducted as a Stage II investigation.

- If laboratory results indicate the presence of COPCs above PALs, then a CADD will be prepared. 
- If no COPCs are identified above PALs, then a CADD/Closure Report will be prepared according to the outline agreed upon by NDEP and DOE/NV. This type of CADD incorporates the elements of the regular CADD and the closure report and serves as the closure report for the site. 


\section{A.7.0 Decision Error}

Biased sampling locations will be selected for sampling at CAU 232 as identified in Sections A.4.0, A.5.0, and A.6.0. The sampling strategy targets worst-case contamination by sampling the sewage lagoon system soil at points with highest potential for contamination. Biased sampling will be performed at the outfall of the lagoons and swale and will target areas where ponding may have occurred. Confidence levels and sampling errors agreed to by the DOE/NV and the NDEP will be used to calculate the total number of samples required.

This sampling strategy will ensure that the extent of the contamination has been adequately located and identified. Two consecutive samples below field screening levels will be obtained from the predetermined sampling locations in soil borings to define the lower limit of the affected soils, if any. Field screening results for these samples will be confirmed by off-site laboratory analysis.

\section{A.7.1 Confidence Levels for Volatile Organic Compounds Analysis}

The indicator parameters for CAU 232 are VOCs. Field screening for VOCs will be accomplished using the HNU Model DL-101 Photoionization Detector. Laboratory analysis will utilize SW-846 Method 8260B (EPA, 1996).

The SW-846 Method 8260B (EPA, 1996) gives individual coefficients of variation (CVs) or relative standard deviation (RSDs) for each analyte determined by the method. While these range from as low as 3.5 percent to as high as 39.6 percent, for garden soil spiked at the $4 \mathrm{mg} / \mathrm{kg}$ level, the average $\mathrm{CV}$ or RSDs is approximately 7.5 percent. For the purposes of this investigation, the $\mathrm{CV}$ or RSDs will be assumed to be 10 percent.

A relative error of 10 - 20 percent from the true mean at a confidence limit of 90 percent is considered acceptable for planned removal and remedial response studies (EPA, 1989). 
Equation 8 from Chapter 9 of SW-846 (EPA, 1996) gives the number of samples required to determine the mean value of a given parameter to within a specified percent error, $\mathrm{e}_{\mathrm{r}}$, with a confidence limit of 90 percent, using an analytical method with a $\mathrm{CV}$, as

$$
\mathrm{n}=\left(\mathrm{t}_{0.90, \mathrm{n}-1} \mathrm{CV} / \mathrm{e}_{\mathrm{r}}\right)^{2}
$$

where " $t$ " is the one-tailed 90 percent Student's " $t$ " value for the appropriate number of degrees of freedom (n-1).

Substituting the appropriate values for " $\mathrm{t}$ " (Taylor, 1990), CV (10 percent) and $\mathrm{e}_{\mathrm{r}}$ (10 percent) into this equation and iterating the equation several times gives $n=2.7$, which rounds up to $n=3$ (Hersh, 1999). Thus, collecting samples from three locations per waste lagoon will allow the determination of the VOCs concentration within 10 percent of the true mean at a confidence limit of 90 percent. 


\section{A.8.0 References}

Adams, S.R. 1998. Memo to D. Arnold regarding "Daily Response Check of Fidler at the Double Tracks RADSAFE Area," 16 June. Las Vegas, NV: IT Corporation.

Adams, S. (IT Corporation). 1999. Record of telecon with L. Linden (SAIC) regarding Area 25 Sewage Lagoons, 14 January. Las Vegas, NV.

BN, see Bechtel Nevada.

Bechtel Nevada. 1996. Memorandum to D. Elle (DOE/NV) regarding quarterly discharge monitoring report for the Nevada Test Site sewage lagoons for October 1, 1995 through December 31, 1995, 04 January. Las Vegas, NV.

Bielawski. J. 1998. Record of telecon with L. Linden (SAIC) regarding Area 25 Sewage Lagoons, 28 December. Las Vegas, NV.

DOE/NV, see U.S. Department of Energy, Nevada Operations Office.

Edwards, D. (U.S. Geological Survey). 1998. Record of telecon with L. Linden (SAIC) regarding U.S. Geological Survey personnel occupying Test Cell 'C' Building 3229, 16 December. Las Vegas, NV.

EG\&G/EM, see EG\&G Energy Measurements.

EG\&G Energy Measurements. 1973. Aerial photo of TCC and Sewage Lagoons. Nellis Air Force Base, NV: RSL Photo Archive Library.

EPA, see U.S. Environmental Protection Agency.

Frazier, A.R. (Reynolds Electrical \& Engineering Company, Inc.). 1988. Letter to F. E. Bingham (DOE/NV) regarding the operations and maintenance plans of the Nevada Test Site - Area 25 sewage disposal systems, 15 June. Las Vegas, NV.

Hale, G.S., and C.L. Westenburg. 1995. Selected Ground-Water Data for Yucca Mountain Region, Southern Nevada and Eastern California, Calendar Year 1993, Open-File Report 95-158. Carson City, NV.

Hersh, S.D. (IT Corporation). 1998. Memorandum to File entitled "SDG 15720 Chemical Data Evaluation Summary," 21 January. Las Vegas, NV. 
Hersh, S.D. (IT Corporation). 1999. Memorandum regarding confidence levels for VOA analysis at CAU 232, 06 January. Las Vegas, NV.

IT, see IT Corporation.

IT Corporation. 1997. Ground-level photograph of a stained outfall and remains of waste under discharge pipe in the west lagoon, number 250301p5, 18 September. Las Vegas, NV.

IT Corporation. 1999. Ground-level survey results of Area 25 Sewage Lagoons. Las Vegas, NV.

Laczniak, R.J., J.C. Cole, D.A. Sawyer, and D.A. Trudeau. 1996. Summary of Hydrogeologic Controls on Ground-Water Flow at the Nevada Test Site, Nye County, Nevada, U.S. Geological Survey Water-Resources Investigations Report 96-4109. Denver, CO: U.S. Geological Survey.

LANL, see Los Alamos National Laboratory.

Los Alamos National Laboratory. 1965a. “KIWI Transient Nuclear Test,” videotape Y-132. Prepared for the U.S. Atomic Energy Commission. Los Alamos, NM.

Los Alamos National Laboratory. 1965b. "Modification of Test Cell 'C',' videotape Y-141. Prepared for the U.S. Atomic Energy Commission. Los Alamos, NM.

Los Alamos National Laboratory. 1968. “Nuclear Propulsion in Space NASA/AEC,” F21 videotape. Prepared for the U.S. Atomic Energy Commission. Los Alamos, NM.

Meyers, J.S., and T.J. Nordenson. 1962. Evaporation from the 17 Western States With a Section on Evaporation Rates, U.S. Geological Survey Professional Paper 272-D. Denver, CO: U.S. Geological Survey.

Morgan, T. (Bechtel Nevada). 1998. Record of telecon with L. Linden (SAIC) regarding Area 25 Sewage Lagoons, 07 December. Las Vegas, NV.

Moore, E. (Bechtel Nevada). 1998. Record of telecon with L. Linden (SAIC) regarding Area 25 Sewage Lagoons, 08 December. Las Vegas, NV.

Moore, J.M. (Science Applications International Corporation). 1999. Memorandum to M. Todd regarding Background Concentrations for NTS and TTR Soil Samples, 03 February. Las Vegas, NV.

NAC, see Nevada Administrative Code.

NBMG, see Nevada Bureau of Mines and Geology. 
Nevada Administrative Code. 1998. NAC 445A.2272b, "Contamination of Soil: Establishment of Action Levels." Carson City, NV: Nevada Division of Environmental Protection.

Nevada Bureau of Mines and Geology. 1998. Mineral and Energy Resource Assessment of the Nellis Air Force Range, Open-File Report 98-1. Reno, NV.

NRC, see U.S. Nuclear Regulatory Commission.

REECo, see Reynolds Electrical \& Engineering Company, Inc.

Reynolds Electrical \& Engineering Company, Inc. 1966. Engineering drawing of the operations building 3229, Test Cell 'C' sewage lagoon plan and details, number 3229-SP-5. Las Vegas, NV.

Reynolds Electrical \& Engineering Company, Inc. 1984. Engineering drawings of existing water and sewer layout test Cell 'C' Plan, number 25-TC-C-C1. Las Vegas, NV.

Reynolds Electrical \& Engineering Company, Inc. 1988. Engineering drawing of the modifications to Test Cell 'C' and sewage facility, number 25-TC-C-C41. Las Vegas, NV.

Sanders, F.W. 1968. Decontamination of Test Cell ' $C$ ' at the Nuclear Rocket Development Station After a Reactor Accident, LA-3633-MS. Los Alamos, NM: Los Alamos National Laboratory.

Taylor, J.K. 1990. Statistical Techniques for Data Analysis. Chelsea, MI: Lewis Publishers, Inc.

U.S. Department of Energy, Nevada Operations Office. 1984. Nevada Test Site Area 25 Radiological Survey and Cleanup Project 1974-1983 (a revised final report). Prepared by M.G. Miller. Las Vegas, NV: Reynolds Electrical \& Engineering Company, Inc.

U.S. Department of Energy, Nevada Operations Office. 1996a. Final Environmental Impact Statement for the Nevada Test Site and Off-Site Locations in the State of Nevada, DOE/EIS 0243. Las Vegas, NV.

U.S. Department of Energy, Nevada Operations Office. 1996b. Industrial Sites Quality Assurance Project Plan, DOE/NV--372. Las Vegas, NV.

U.S. Environmental Protection Agency. 1989. Soil Sampling Quality Assurance User's Guide, Second Edition, EPA/600/8-89/046. Washington, DC. 
U.S. Environmental Protection Agency. 1996. Test Methods for Evaluating Solid Waste, Physical/Chemical Methods, SW-846, Third Edition, CD ROM, PB97-501928GEI (CD ROM includes revisions to 1986, 1992, and 1994). Washington, DC.

U.S. Environmental Protection Agency. 1998. Memorandum from S.J. Smucker to PRG table mailing list regarding Region IX Preliminary Remediation Goals, 1 August.

San Francisco, CA.

van Drielen, H. (Nevada Division of Environmental Protection). 1997. Letter to K.A. Hoar (DOE/NV) regarding revision of general Water Pollution Control Permit, 30 April. Las Vegas, NV.

Wahl, R.R., D.A. Sawyer, S.A. Minor, M.D. Carr, J.C. Cole, J.C. Swadley, R.J. Laczniak, R.G. Warren, K.S. Green, and C.M. Engle. 1997. Digital Geological Map Database of the Nevada Test Site, Area, U.S. Geological Survey Open-File Report 97-140. Las Vegas, NV. 
Date: 05/04/99

Page B-1 of B-2

\section{Appendix B}

\section{Project Organization}




\section{B.1.0 Project Organization}

The DOE/NV Industrial Sites Project Manager is Janet Appenzeller-Wing and her telephone number is (702) 295-0461.

The names of the project Health and Safety Officer and the Quality Assurance Officer can be found in the appropriate DOE/NV plan. However, personnel are subject to change, and it is suggested that the DOE/NV Industrial Sites Project Manager be contacted for further information. The DOE/NV Task Manager will be identified in the FFACO Biweekly Activity Report prior to the start of field activities. 


\section{Appendix C}

\section{Laboratory Chemical, Toxicity Characteristic Leaching Procedure, and Radiochemistry Analytical Requirements for Industrial Sites}


Table C.1-1

Laboratory Chemical, Toxicity Characteristic Leaching Procedure, and Radiochemistry Analytical Requirements for Industrial Sites

(Page 1 of 5 )

\begin{tabular}{|c|c|c|c|c|c|c|}
\hline $\begin{array}{c}\text { Parameter or } \\
\text { Analyte }\end{array}$ & $\begin{array}{l}\text { Medium or } \\
\text { Matrix }\end{array}$ & $\begin{array}{l}\text { Analytical } \\
\text { Method }\end{array}$ & $\begin{array}{l}\text { Minimum } \\
\text { Reporting Limit }\end{array}$ & $\begin{array}{l}\text { Regulatory } \\
\text { Limit }\end{array}$ & $\begin{array}{c}\text { Relative } \\
\text { Percent } \\
\text { Difference } \\
\text { (RPD) }^{\mathrm{a}} \\
\end{array}$ & $\begin{array}{c}\text { Percent } \\
\text { Recovery } \\
(\% R)^{b}\end{array}$ \\
\hline \multicolumn{7}{|c|}{ ORGANICS } \\
\hline \multirow{2}{*}{$\begin{array}{c}\text { Total Volatile } \\
\text { Organic Compounds } \\
\text { (VOCs) }\end{array}$} & Water & \multirow{2}{*}{$8260 B^{c}$} & \multirow{2}{*}{$\begin{array}{c}\text { Analyte-specific } \\
\text { estimated } \\
\text { quantitation limits }^{d}\end{array}$} & \multirow{2}{*}{$\begin{array}{l}\text { Not Applicable } \\
\text { (NA) }\end{array}$} & $14^{\mathrm{e}}$ & $61-145^{\mathrm{e}}$ \\
\hline & Soil & & & & $24^{e}$ & $59-172^{\mathrm{e}}$ \\
\hline \multicolumn{7}{|l|}{$\begin{array}{c}\text { Toxicity } \\
\text { Characteristic } \\
\text { Leaching Procedure } \\
\text { (TCLP) VOCs }\end{array}$} \\
\hline Benzene & \multirow{10}{*}{ Aqueous } & \multirow{10}{*}{$1311 / 8260 \mathrm{~B}^{\mathrm{c}}$} & $0.050 \mathrm{mg} / \mathrm{L}^{\mathrm{d}}$ & $0.5 \mathrm{mg} / \mathrm{L}^{\mathrm{d}}$ & \multirow{10}{*}{$14^{\mathrm{e}}$} & \multirow{10}{*}{$61-145^{e}$} \\
\hline $\begin{array}{c}\text { Carbon } \\
\text { Tetrachloride }\end{array}$ & & & $0.050 \mathrm{mg} / \mathrm{L}^{\mathrm{d}}$ & $0.5 \mathrm{mg} / \mathrm{L}^{\mathrm{d}}$ & & \\
\hline Chlorobenzene & & & $0.050 \mathrm{mg} / \mathrm{L}^{\mathrm{d}}$ & $100 \mathrm{mg} / \mathrm{L}^{\mathrm{d}}$ & & \\
\hline Chloroform & & & $0.050 \mathrm{mg} / \mathrm{L}^{\mathrm{d}}$ & $6 \mathrm{mg} / \mathrm{L}^{\mathrm{d}}$ & & \\
\hline 1,2-Dichloroethane & & & $0.050 \mathrm{mg} / \mathrm{L}^{\mathrm{d}}$ & $0.5 \mathrm{mg} / \mathrm{L}^{\mathrm{d}}$ & & \\
\hline 1,1-Dichloroethene & & & $0.050 \mathrm{mg} / \mathrm{L}^{\mathrm{d}}$ & $0.7 \mathrm{mg} / \mathrm{L}^{\mathrm{d}}$ & & \\
\hline Methyl Ethyl Ketone & & & $0.050 \mathrm{mg} / \mathrm{L}^{\mathrm{d}}$ & $200 \mathrm{mg} / \mathrm{L}^{\mathrm{d}}$ & & \\
\hline Tetrachloroethene & & & $0.050 \mathrm{mg} / \mathrm{L}^{\mathrm{d}}$ & $0.7 \mathrm{mg} / \mathrm{L}^{\mathrm{d}}$ & & \\
\hline Trichloroethene & & & $0.050 \mathrm{mg} / \mathrm{L}^{\mathrm{d}}$ & $0.5 \mathrm{mg} / \mathrm{L}^{\mathrm{d}}$ & & \\
\hline Vinyl Chloride & & & $0.050 \mathrm{mg} / \mathrm{L}^{\mathrm{d}}$ & $0.2 \mathrm{mg} / \mathrm{L}^{\mathrm{d}}$ & & \\
\hline \multirow{2}{*}{$\begin{array}{l}\text { Total Semivolatile } \\
\text { Organic Compounds } \\
\text { (SVOCs) }\end{array}$} & Water & \multirow{2}{*}{$8270 C^{c}$} & \multirow{2}{*}{$\begin{array}{c}\text { Analyte-specific } \\
\text { estimated } \\
\text { quantitation limits }^{d}\end{array}$} & \multirow{2}{*}{ NA } & $50^{\circ}$ & $9-127^{e}$ \\
\hline & Soil & & & & $50^{\mathrm{e}}$ & $11-142^{\mathrm{e}}$ \\
\hline \multicolumn{7}{|l|}{ TCLP SVOCs } \\
\hline o-Cresol & \multirow{6}{*}{ Aqueous } & \multirow{6}{*}{$1311 / 8270 C^{c}$} & $0.10 \mathrm{mg} / \mathrm{L}^{\mathrm{d}}$ & $200 \mathrm{mg} / \mathrm{L}^{\mathrm{d}}$ & \multirow{6}{*}{$50^{e}$} & \multirow{6}{*}{$9-127^{e}$} \\
\hline m-Cresol & & & $0.10 \mathrm{mg} / \mathrm{L}^{\mathrm{d}}$ & $200 \mathrm{mg} / \mathrm{L}^{\mathrm{d}}$ & & \\
\hline p-Cresol & & & $0.10 \mathrm{mg} / \mathrm{L}^{\mathrm{d}}$ & $200 \mathrm{mg} / \mathrm{L}^{\mathrm{d}}$ & & \\
\hline Cresol (total) & & & $0.30 \mathrm{mg} / \mathrm{L}^{d}$ & $200 \mathrm{mg} / \mathrm{L}^{\mathrm{d}}$ & & \\
\hline $\begin{array}{l}\text { 1,4-Dichloro- } \\
\text { benzene }\end{array}$ & & & $0.10 \mathrm{mg} / \mathrm{L}^{\mathrm{d}}$ & $7.5 \mathrm{mg} / \mathrm{L}^{\mathrm{d}}$ & & \\
\hline 2,4-Dinitrotoluene & & & $0.10 \mathrm{mg} / \mathrm{L}^{d}$ & $0.13 \mathrm{mg} / \mathrm{L}^{d}$ & & \\
\hline
\end{tabular}


Table C.1-1

\section{Laboratory Chemical, Toxicity Characteristic Leaching Procedure, and Radiochemistry Analytical Requirements for Industrial Sites}

(Page 2 of 5 )

\begin{tabular}{|c|c|c|c|c|c|c|}
\hline $\begin{array}{c}\text { Parameter or } \\
\text { Analyte }\end{array}$ & $\begin{array}{l}\text { Medium or } \\
\text { Matrix }\end{array}$ & $\begin{array}{l}\text { Analytical } \\
\text { Method }\end{array}$ & $\begin{array}{c}\text { Minimum } \\
\text { Reporting Limit }\end{array}$ & $\begin{array}{l}\text { Regulatory } \\
\text { Limit }\end{array}$ & $\begin{array}{c}\text { Relative } \\
\text { Percent } \\
\text { Difference } \\
\text { (RPD) }^{\mathrm{a}} \\
\end{array}$ & $\begin{array}{c}\text { Percent } \\
\text { Recovery } \\
(\% \mathrm{R})^{\mathrm{b}}\end{array}$ \\
\hline $\begin{array}{l}\text { Hexachloro- } \\
\text { benzene }\end{array}$ & \multirow{8}{*}{ Aqueous } & \multirow{8}{*}{$1311 / 8270 C^{c}$} & $0.10 \mathrm{mg} / \mathrm{L}^{\mathrm{d}}$ & $0.13 \mathrm{mg} / \mathrm{L}^{\mathrm{d}}$ & \multirow{8}{*}{$50^{e}$} & \multirow{8}{*}{$9-127^{e}$} \\
\hline $\begin{array}{l}\text { Hexachloro- } \\
\text { butadiene }\end{array}$ & & & $0.10 \mathrm{mg} / \mathrm{L}^{d}$ & $0.5 \mathrm{mg} / \mathrm{L}^{\mathrm{d}}$ & & \\
\hline $\begin{array}{l}\text { Hexachloro- } \\
\text { ethane }\end{array}$ & & & $0.10 \mathrm{mg} / \mathrm{L}^{\mathrm{d}}$ & $3 \mathrm{mg} / \mathrm{L}^{\mathrm{d}}$ & & \\
\hline Nitrobenzene & & & $0.10 \mathrm{mg} / \mathrm{L}^{\mathrm{d}}$ & $2 \mathrm{mg} / \mathrm{L}^{\mathrm{d}}$ & & \\
\hline $\begin{array}{l}\text { Pentachloro- } \\
\text { phenol }\end{array}$ & & & $0.50 \mathrm{mg} / \mathrm{L}^{\mathrm{d}}$ & $100 \mathrm{mg} / \mathrm{L}^{\mathrm{d}}$ & & \\
\hline Pyridine & & & $0.10 \mathrm{mg} / \mathrm{L}^{\mathrm{d}}$ & $5 \mathrm{mg} / \mathrm{L}^{\mathrm{d}}$ & & \\
\hline $\begin{array}{l}\text { 2,4,5-Trichloro- } \\
\text { phenol }\end{array}$ & & & $0.10 \mathrm{mg} / \mathrm{L}^{\mathrm{d}}$ & $400 \mathrm{mg} / \mathrm{L}^{\mathrm{d}}$ & & \\
\hline $\begin{array}{c}\text { 2,4,6-Trichloro- } \\
\text { phenol }\end{array}$ & & & $0.10 \mathrm{mg} / \mathrm{L}^{\mathrm{d}}$ & $2 \mathrm{mg} / \mathrm{L}^{\mathrm{d}}$ & & \\
\hline \multirow{2}{*}{$\begin{array}{c}\text { Total } \\
\text { Pesticides }\end{array}$} & Water & \multirow{2}{*}{$8081 A^{c}$} & \multirow{2}{*}{$\begin{array}{l}\text { Analyte-specific } \\
\qquad(\mathrm{CRQL})^{\mathrm{e}}\end{array}$} & \multirow{2}{*}{ NA } & $27^{\mathrm{e}}$ & $38-131^{e}$ \\
\hline & Soil & & & & $50^{\mathrm{e}}$ & $23-139^{e}$ \\
\hline \multicolumn{7}{|l|}{$\begin{array}{c}\text { TCLP } \\
\text { Pesticides }\end{array}$} \\
\hline Chlordane & \multirow{7}{*}{ Aqueous } & \multirow{7}{*}{$1311 / 8081 A^{c}$} & $0.0005 \mathrm{mg} / \mathrm{L}^{\mathrm{e}}$ & $0.03 \mathrm{mg} / \mathrm{L}^{\mathrm{d}}$ & \multirow{7}{*}{$27^{e}$} & \multirow{7}{*}{$38-131^{e}$} \\
\hline Endrin & & & $0.001 \mathrm{mg} / \mathrm{L}^{\mathrm{e}}$ & $0.02 \mathrm{mg} / \mathrm{L}^{\mathrm{d}}$ & & \\
\hline Heptachlor & & & $0.0005 \mathrm{mg} / \mathrm{L}^{\mathrm{e}}$ & $0.008 \mathrm{mg} / \mathrm{L}^{\mathrm{d}}$ & & \\
\hline $\begin{array}{l}\text { Heptachlor } \\
\text { Epoxide }\end{array}$ & & & $0.0005 \mathrm{mg} / \mathrm{L}^{\mathrm{e}}$ & $0.008 \mathrm{mg} / \mathrm{L}^{\mathrm{d}}$ & & \\
\hline $\begin{array}{c}\text { gamma-BHC } \\
\text { (Lindane) }\end{array}$ & & & $0.0005 \mathrm{mg} / \mathrm{L}^{\mathrm{e}}$ & $0.4 \mathrm{mg} / \mathrm{L}^{\mathrm{d}}$ & & \\
\hline Methoxychlor & & & $0.005 \mathrm{mg} / \mathrm{L}^{\mathrm{e}}$ & $10 \mathrm{mg} / \mathrm{L}^{\mathrm{d}}$ & & \\
\hline Toxaphene & & & $0.05 \mathrm{mg} / \mathrm{L}^{\mathrm{e}}$ & $0.5 \mathrm{mg} / \mathrm{L}^{\mathrm{d}}$ & & \\
\hline \multirow[b]{2}{*}{$\begin{array}{l}\text { Polychlorinated } \\
\text { Biphenyls (PCBs) }\end{array}$} & Water & \multirow[b]{2}{*}{$8082^{c}$} & \multirow{2}{*}{$\begin{array}{c}\text { Analyte-specific } \\
\text { contract required } \\
\text { quantitation limits } \\
(\mathrm{CRQL})^{\mathrm{e}}\end{array}$} & \multirow[b]{2}{*}{ NA } & \multirow[b]{2}{*}{ Lab-specific ${ }^{f}$} & \multirow[b]{2}{*}{ Lab-specific $^{f}$} \\
\hline & Soil & & & & & \\
\hline \multirow{2}{*}{$\begin{array}{c}\text { Total } \\
\text { Herbicides }\end{array}$} & Water & \multirow{2}{*}{$8151 A^{c}$} & $1.3 \mu \mathrm{g} / \mathrm{L}^{\mathrm{c}}$ & \multirow{2}{*}{ NA } & \multirow{2}{*}{ Lab-specific $^{f}$} & \multirow{2}{*}{ Lab-specific ${ }^{f}$} \\
\hline & Soil & & $66 \mu \mathrm{g} / \mathrm{kg}^{\mathrm{c}}$ & & & \\
\hline \multicolumn{7}{|l|}{$\begin{array}{c}\text { TCLP } \\
\text { Herbicides }\end{array}$} \\
\hline 2,4-D & \multirow{2}{*}{ Aqueous } & \multirow{2}{*}{$1311 / 8151 A^{c}$} & $0.002 \mathrm{mg} / \mathrm{L}^{\mathrm{d}}$ & $10 \mathrm{mg} / \mathrm{L}^{\mathrm{d}}$ & \multirow{2}{*}{ Lab-specific ${ }^{f}$} & \multirow{2}{*}{ Lab-specific $^{\dagger}$} \\
\hline $2,4,5-\mathrm{TP}$ & & & $0.00075 \mathrm{mg} / \mathrm{L}^{d}$ & $1 \mathrm{mg} / \mathrm{L}^{\mathrm{d}}$ & & \\
\hline
\end{tabular}


Table C.1-1

\section{Laboratory Chemical, Toxicity Characteristic Leaching Procedure, and Radiochemistry Analytical Requirements for Industrial Sites}

(Page 3 of 5 )

\begin{tabular}{|c|c|c|c|c|c|c|}
\hline $\begin{array}{c}\text { Parameter or } \\
\text { Analyte }\end{array}$ & $\begin{array}{l}\text { Medium or } \\
\text { Matrix }\end{array}$ & $\begin{array}{l}\text { Analytical } \\
\text { Method }\end{array}$ & $\begin{array}{l}\text { Minimum } \\
\text { Reporting Limit }\end{array}$ & $\begin{array}{l}\text { Regulatory } \\
\text { Limit }\end{array}$ & $\begin{array}{c}\text { Relative } \\
\text { Percent } \\
\text { Difference } \\
\text { (RPD) }^{\mathrm{a}}\end{array}$ & $\begin{array}{c}\text { Percent } \\
\text { Recovery } \\
(\% R)^{b}\end{array}$ \\
\hline \multirow{4}{*}{$\begin{array}{c}\text { Total Petroleum } \\
\text { Hydrocarbons (TPH) }\end{array}$} & $\begin{array}{c}\text { Water } \\
\text { Gasoline }\end{array}$ & \multirow{4}{*}{ 8015B modified ${ }^{c}$} & $0.1 \mathrm{mg} / \mathrm{L}^{\mathrm{g}}$ & \multirow{4}{*}{ NA } & \multirow{4}{*}{ Lab-specific $^{\dagger}$} & \multirow{4}{*}{ Lab-specific $^{\dagger}$} \\
\hline & Soil Gasoline & & $0.5 \mathrm{mg} / \mathrm{kg}^{\mathrm{g}}$ & & & \\
\hline & Water Diesel & & $0.5 \mathrm{mg} / \mathrm{L}^{\mathrm{g}}$ & & & \\
\hline & Soil Diesel & & $25 \mathrm{mg} / \mathrm{kg}^{\mathrm{g}}$ & & & \\
\hline \multirow{2}{*}{ Explosives } & Water & \multirow{2}{*}{$8330^{c}$} & $14 \mu \mathrm{g} / \mathrm{L}^{\mathrm{c}}$ & \multirow{2}{*}{ NA } & \multirow{2}{*}{ Lab-specific $^{\dagger}$} & \multirow{2}{*}{ Lab-specific $^{\dagger}$} \\
\hline & Soil & & $2.2 \mathrm{mg} / \mathrm{kg}^{\mathrm{c}}$ & & & \\
\hline \multirow{2}{*}{$\begin{array}{c}\text { Polychlorinated } \\
\text { Dioxins and Furans }\end{array}$} & Water & \multirow{2}{*}{$8280 \mathrm{~A} / 8290^{c}$} & $0.05 \mu \mathrm{g} / \mathrm{L}^{\mathrm{c}}$ & \multirow{2}{*}{ NA } & \multirow{2}{*}{ Lab-specific $^{\dagger}$} & \multirow{2}{*}{ Lab-specific $^{\dagger}$} \\
\hline & Soil & & $5 \mu \mathrm{g} / \mathrm{kg}^{\mathrm{c}}$ & & & \\
\hline \multicolumn{7}{|c|}{ INORGANICS } \\
\hline \multicolumn{7}{|l|}{$\begin{array}{c}\text { Total Resource } \\
\text { Conservation and } \\
\text { Recovery Act } \\
\text { (RCRA) Metals }\end{array}$} \\
\hline \multirow{2}{*}{ Arsenic } & Water & $6010 \mathrm{~B} / 7470 \mathrm{~A}^{\mathrm{c}}$ & $10 \mu \mathrm{g} / \mathrm{L}^{\mathrm{g}, \mathrm{h}}$ & \multirow{16}{*}{ NA } & \multirow{16}{*}{$20^{h}$} & \multirow{16}{*}{$75-125^{h}$} \\
\hline & Soil & $6010 \mathrm{~B} / 7471 \mathrm{~A}^{\mathrm{c}}$ & $1 \mathrm{mg} / \mathrm{kg}^{\mathrm{g}, \mathrm{h}}$ & & & \\
\hline \multirow{2}{*}{ Barium } & Water & $6010 \mathrm{~B} / 7470 \mathrm{~A}^{\mathrm{c}}$ & $200 \mu \mathrm{g} / \mathrm{L}^{\mathrm{g}, \mathrm{h}}$ & & & \\
\hline & Soil & $6010 \mathrm{~B} / 7471 \mathrm{~A}^{\mathrm{c}}$ & $20 \mathrm{mg} / \mathrm{kg}^{\mathrm{g}, \mathrm{h}}$ & & & \\
\hline \multirow{2}{*}{ Cadmium } & Water & $6010 \mathrm{~B} / 7470 \mathrm{~A}^{\mathrm{c}}$ & $5 \mu \mathrm{g} / \mathrm{L}^{\mathrm{g}, \mathrm{h}}$ & & & \\
\hline & Soil & $6010 \mathrm{~B} / 7471 \mathrm{~A}^{\mathrm{c}}$ & $0.5 \mathrm{mg} / \mathrm{kg}^{\mathrm{g}, \mathrm{h}}$ & & & \\
\hline \multirow{2}{*}{ Chromium } & Water & $6010 \mathrm{~B} / 7470 \mathrm{~A}^{\mathrm{c}}$ & $10 \mu \mathrm{g} / \mathrm{L}^{\mathrm{g}, \mathrm{h}}$ & & & \\
\hline & Soil & $6010 \mathrm{~B} / 7471 \mathrm{~A}^{\mathrm{c}}$ & $1 \mathrm{mg} / \mathrm{kg}^{\mathrm{g}, \mathrm{h}}$ & & & \\
\hline \multirow{2}{*}{ Lead } & Water & $6010 \mathrm{~B} / 7470 \mathrm{~A}^{\mathrm{c}}$ & $3 \mu \mathrm{g} / \mathrm{L}^{\mathrm{g}, \mathrm{h}}$ & & & \\
\hline & Soil & $6010 \mathrm{~B} / 7471 \mathrm{~A}^{\mathrm{c}}$ & $0.3 \mathrm{mg} / \mathrm{kg}^{\mathrm{g}, \mathrm{h}}$ & & & \\
\hline \multirow{2}{*}{ Mercury } & Water & $6010 \mathrm{~B} / 7470 \mathrm{~A}^{\mathrm{c}}$ & $0.2 \mu \mathrm{g} / \mathrm{L}^{\mathrm{g}, \mathrm{h}}$ & & & \\
\hline & Soil & $6010 \mathrm{~B} / 7471 \mathrm{~A}^{\mathrm{c}}$ & $0.1 \mathrm{mg} / \mathrm{kg}^{\mathrm{g}, \mathrm{h}}$ & & & \\
\hline \multirow{2}{*}{ Selenium } & Water & $6010 \mathrm{~B} / 7470 \mathrm{~A}^{\mathrm{c}}$ & $5 \mu \mathrm{g} / \mathrm{L}^{\mathrm{g}, \mathrm{h}}$ & & & \\
\hline & Soil & $6010 \mathrm{~B} / 7471 \mathrm{~A}^{\mathrm{c}}$ & $0.5 \mathrm{mg} / \mathrm{kg}^{\mathrm{g}, \mathrm{h}}$ & & & \\
\hline \multirow{2}{*}{ Silver } & Water & $6010 \mathrm{~B} / 7470 \mathrm{~A}^{\mathrm{c}}$ & $10 \mu \mathrm{g} / \mathrm{L}^{\mathrm{g}, \mathrm{h}}$ & & & \\
\hline & Soil & $6010 \mathrm{~B} / 7471 \mathrm{~A}^{\mathrm{c}}$ & $1 \mathrm{mg} / \mathrm{kg}^{\mathrm{g}, \mathrm{h}}$ & & & \\
\hline
\end{tabular}


Table C.1-1

\section{Laboratory Chemical, Toxicity Characteristic Leaching Procedure, and Radiochemistry Analytical Requirements for Industrial Sites}

(Page 4 of 5 )

\begin{tabular}{|c|c|c|c|c|c|c|}
\hline $\begin{array}{l}\text { Parameter or } \\
\text { Analyte }\end{array}$ & $\begin{array}{l}\text { Medium or } \\
\text { Matrix }\end{array}$ & $\begin{array}{l}\text { Analytical } \\
\text { Method }\end{array}$ & $\begin{array}{c}\text { Minimum } \\
\text { Reporting Limit }\end{array}$ & $\begin{array}{l}\text { Regulatory } \\
\text { Limit }\end{array}$ & $\begin{array}{c}\text { Relative } \\
\text { Percent } \\
\text { Difference } \\
\text { (RPD) }^{\mathrm{a}}\end{array}$ & $\begin{array}{c}\text { Percent } \\
\text { Recovery } \\
(\% R)^{b}\end{array}$ \\
\hline \multicolumn{7}{|l|}{$\begin{array}{l}\text { TCLP RCRA } \\
\text { Metals }\end{array}$} \\
\hline Arsenic & \multirow{8}{*}{ Aqueous } & \multirow{8}{*}{$\begin{array}{l}1311 / 6010 B^{c} \\
1311 / 7470 A^{c}\end{array}$} & $0.10 \mathrm{mg} / \mathrm{L}^{\mathrm{g}, \mathrm{h}}$ & $5 \mathrm{mg} / \mathrm{L}^{\mathrm{d}}$ & \multirow{8}{*}{$20^{\mathrm{h}}$} & \multirow{8}{*}{$75-125^{h}$} \\
\hline Barium & & & $2 \mathrm{mg} / \mathrm{L}^{\mathrm{g}, \mathrm{h}}$ & $100 \mathrm{mg} / \mathrm{L}^{\mathrm{d}}$ & & \\
\hline Cadmium & & & $0.05 \mathrm{mg} / \mathrm{L}^{\mathrm{g}, \mathrm{h}}$ & $1 \mathrm{mg} / \mathrm{L}^{\mathrm{d}}$ & & \\
\hline Chromium & & & $0.10 \mathrm{mg} / \mathrm{L}^{\mathrm{g}, \mathrm{h}}$ & $5 \mathrm{mg} / \mathrm{L}^{\mathrm{d}}$ & & \\
\hline Lead & & & $0.03 \mathrm{mg} / \mathrm{L}^{\mathrm{g}, \mathrm{h}}$ & $5 \mathrm{mg} / \mathrm{L}^{\mathrm{d}}$ & & \\
\hline Mercury & & & $0.002 \mathrm{mg} / \mathrm{L}^{\mathrm{g}, \mathrm{h}}$ & $0.2 \mathrm{mg} / \mathrm{L}^{\mathrm{d}}$ & & \\
\hline Selenium & & & $0.05 \mathrm{mg} / \mathrm{L}^{\mathrm{g}, \mathrm{h}}$ & $1 \mathrm{mg} / \mathrm{L}^{\mathrm{d}}$ & & \\
\hline Silver & & & $0.10 \mathrm{mg} / \mathrm{L}^{\mathrm{g}, \mathrm{h}}$ & $5 \mathrm{mg} / \mathrm{L}^{\mathrm{d}}$ & & \\
\hline \multirow{2}{*}{ Cyanide } & Water & \multirow{2}{*}{$9010 \mathrm{~B}^{\mathrm{c}}$} & $0.01 \mathrm{mg} / \mathrm{L}^{\mathrm{h}}$ & \multirow{2}{*}{ NA } & \multirow{2}{*}{$20^{\mathrm{h}}$} & \multirow{2}{*}{$75-125^{\mathrm{h}}$} \\
\hline & Soil & & $1.0 \mathrm{mg} / \mathrm{kg}^{\mathrm{h}}$ & & & \\
\hline \multirow[b]{2}{*}{ Sulfide } & Water & \multirow[b]{2}{*}{$9030 \mathrm{~B} / 9034^{\mathrm{C}}$} & $0.4 \mathrm{mg} / \mathrm{L}^{\mathrm{c}}$ & \multirow[b]{2}{*}{ NA } & \multirow[b]{2}{*}{ Lab-specific } & \multirow[b]{2}{*}{ Lab-specific ${ }^{f}$} \\
\hline & $\begin{array}{c}\text { Soil or } \\
\text { Sediment }\end{array}$ & & $10 \mathrm{mg} / \mathrm{kg}^{\mathrm{g}}$ & & & \\
\hline \multirow{2}{*}{ pH/Corrosivity } & Water & $9040 \mathrm{~B}^{\mathrm{c}}$ & \multirow{2}{*}{ NA } & $\mathrm{pH}>2^{\mathrm{i}}$ & \multirow{2}{*}{ Lab-specific $^{f}$} & \multirow{2}{*}{ Lab-specific ${ }^{f}$} \\
\hline & Soil & $9045 C^{c}$ & & $\mathrm{pH}<12.5^{\mathrm{i}}$ & & \\
\hline \multirow[b]{2}{*}{ Ignitability } & Water & $1010^{c}$ & \multirow[b]{2}{*}{ NA } & $\begin{array}{l}\text { Flash Point } \\
<140^{\circ} F^{d}\end{array}$ & \multirow[b]{2}{*}{ NA } & \multirow[b]{2}{*}{ NA } \\
\hline & Soil & $1030^{c}$ & & $\begin{array}{c}\text { Burn Rate }^{\mathrm{c}} \\
>2.2 \mathrm{~mm} / \mathrm{sec} \\
\text { nonmetals; } \\
>0.17 \mathrm{~mm} / \mathrm{sec} \\
\quad \text { metals }\end{array}$ & & \\
\hline \multicolumn{7}{|c|}{ RADIOCHEMISTRY } \\
\hline \multirow{2}{*}{$\begin{array}{l}\text { Gamma-emitting } \\
\text { Radionuclides }\end{array}$} & Water & EPA $901.1^{k}$ & \multirow{2}{*}{ Isotope-specific ${ }^{m}$} & \multirow{2}{*}{ NA } & 20 & \multirow{8}{*}{$\begin{array}{c}\text { Tracer Yield } \\
30-105 \\
\text { Laboratory } \\
\text { Control } \\
\text { Sample Yield } \\
80-120\end{array}$} \\
\hline & Soil & HASL $300^{\prime}$ & & & 35 & \\
\hline & Water & & $2 \mathrm{pCi} / \mathrm{L}$ & & 20 & \\
\hline $\begin{array}{l}\text { Isotopic } \\
\text { Plutonium }\end{array}$ & Soil & NAS-NS-3058 & $\begin{array}{c}0.1 \mathrm{pCi} / \mathrm{g} \\
\mathrm{Pu}-238^{\mathrm{p}} \\
0.4 \mathrm{pCi} / \mathrm{g} \\
\mathrm{Pu}-239 / 240^{\mathrm{p}}\end{array}$ & NA & 35 & \\
\hline \multirow{2}{*}{$\begin{array}{l}\text { Isotopic } \\
\text { Uranium }\end{array}$} & Water & \multirow{2}{*}{ NAS-NS-3050 $0^{q, r}$} & $2 \mathrm{pCi} / \mathrm{L}$ & \multirow{2}{*}{ NA } & 20 & \\
\hline & Soil & & $1 \mathrm{pCi} / \mathrm{g}$ & & 35 & \\
\hline \multirow{2}{*}{ Strontium - $90^{j}$} & Water & SM 7500-Srs & $8 \mathrm{pCi} / \mathrm{L}^{\mathrm{t}}$ & $N A$ & 20 & \\
\hline & Soil & Martin $79^{u}$ & $1 \mathrm{pCi} / \mathrm{g}^{v}$ & 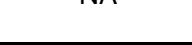 & 35 & \\
\hline
\end{tabular}




\section{Table C.1-1 \\ Laboratory Chemical, Toxicity Characteristic Leaching Procedure, and Radiochemistry Analytical Requirements for Industrial Sites} (Page 5 of 5 )

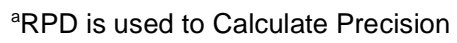

Precision is estimated from the relative percent difference of the concentrations measured for the matrix spike and matrix spike duplicate analyses of unspiked field samples, or field duplicates of unspiked samples. It is calculated by:

$\operatorname{RPD}=100 \times\left\{\left(\left|\mathrm{C}_{1}-\mathrm{C}_{2}\right|\right) /\left[\left(\mathrm{C}_{1}+\mathrm{C}_{2}\right) / 2\right]\right\}$, where $\mathrm{C}_{1}=$ Concentration of the analyte in the first sample aliquot, $\mathrm{C}_{2}=$ Concentration of the analyte in the second sample aliquot.

bo R is used to Calculate Accuracy

Accuracy is assessed from the recovery of analytes spiked into a blank or sample matrix of interest, or from the recovery of surrogate compounds spiked into each sample. The recovery of each spiked analyte is calculated by: $\% R=100 \times\left(C_{s}-C_{u} / C_{n}\right)$, where $C_{s}=$ Concentration of the analyte in the spiked sample, $C_{u}=$ Concentration of the analyte in the unspiked sample,

$\mathrm{C}_{\mathrm{n}}=$ Concentration increase that should result from spiking the sample

'U.S. Environmental Protection Agency (EPA) Test Methods for Evaluating Solid Waste, 3rd Edition, Parts 1-4, SW-846

(EPA, 1996)

${ }^{d}$ Estimated Quantitation Limit as given in SW-846 (EPA, 1996)

eEPA Contract Laboratory Program Statement of Work for Organic Analysis (EPA, 1988b; 1990; 1991; and 1994b)

' In-House Generated RPD and \%R Performance Criteria

It is necessary for laboratories to develop in-house performance criteria and compare them to those in the methods. The laboratory begins by analyzing 15-20 samples of each matrix and calculating the mean \%R for each analyte. The standard deviation (SD) of each \%R is then calculated, and the warning and control limits for each analyte are established at \pm 2 SD and \pm 3 SD from the mean, respectively. If the warning limit is exceeded during the analysis of any sample delivery group (SDG), the laboratory institutes corrective action to bring the analytical system back into control. If the control limit is exceeded, the sample results for that SDG are considered unacceptable. These limits are reviewed after every 20-30 field samples of the same matrix and are updated at least semiannually. The laboratory tracks trends in both performance and control limits by the use of control charts. The laboratory's compliance with these requirements is confirmed as part of an annual laboratory audit. Similar procedures are followed in order to generate acceptance criteria for precision measurements.

IIndustrial Sites Quality Assurance Project Plan (DOE/NV, 1996)

hEPA Contract Laboratory Program Statement of Work for Inorganic Analysis (EPA, 1988a; 1993; and 1994a)

'RCRA Regulations and Keyword Index, 1998 Edition

IIsotopic minimum detectable concentrations are defined during the DQO process and specified in the CAIP as applicable

kPrescribed Procedures for Measurements of Radioactivity in Drinking Water (EPA, 1980) or equivalent method

'Environmental Measurements Laboratory Procedures Manual (DOE, 1992) or equivalent method

'Isotope-Specific Minimum Reporting Limit to be specified in CAIP

"The Radiochemistry of Plutonium (Coleman, 1965) or equivalent method

-Separation and Preconcentration of Actinides from Acidic Media by Extraction Chromatography (Horwitz, 1993) or equivalent method

${ }^{\mathrm{P}}$ The Nevada Test Site Performance Objective Criteria requirement for certifying that hazardous waste has no added radioactivity requires that the total plutonium (the sum of the Pu-238, 239, 240 concentrations) not exceed $0.5 \mathrm{pCi} / \mathrm{g}$ (BN, 1995)

'The Radiochemistry of Uranium (Grindler, 1962) or equivalent method

'Separation and Preconcentration of Uranium from Acidic Media by Extraction Chromatography (Horwitz, 1992) or equivalent method

sStandard Methods for the Examination of Water and Waste Water (APHA, 1992) or equivalent method

'40 CFR 141.16, Table A, "Average Annual Concentrations Assumed to Produce a Total Body or Organ Dose of $4.0 \mathrm{mrem} / \mathrm{yr}$ " (CFR, 1998)

uDetermination of Strontium-89 and -90 in soil with Total Sample Decomposition (Analytical Chemistry, 1979) or equivalent method

${ }^{\vee}$ The $1.0 \mathrm{pCi} / \mathrm{g}$ concentration is approximately twice the concentration of fallout $\mathrm{Sr}-90$ in background surface soils reported in the "Environmental Monitoring Report for the Proposed Ward Valley California Low-Level Radioactive Waste Facility"

(Atlan-Tech, 1992)

Definitions:

$\mu \mathrm{g} / \mathrm{kg}=$ Microgram(s) per kilogram

$\mathrm{mg} / \mathrm{kg}=$ Milligram(s) per kilogram

$\mathrm{pCi} / \mathrm{L}=$ Picocurie(s) per liter $\mathrm{mg} / \mathrm{L}=$ Milligram(s) per liter

$\mathrm{pCi} / \mathrm{g}=$ Picocurie(s) per gram

$\mu \mathrm{g} / \mathrm{L}=$ Microgram(s) per liter 


\section{C.1.0 References}

APHA, see American Public Health Association.

American Public Health Association. 1992. Standard Methods for the Examination of Water and Waste Water, 18th Edition. Washington, D.C.

Analytical Chemistry. 1979. Determination of Strontium-89 and -90 in Soil with Total Sample Decomposition, October.

Atlan-Tech. 1992. Environmental Monitoring Report for the Proposed Ward Valley California Low-Level Radioactive Waste Facility. Roswell, GA.

Bechtel Nevada. 1998. Bechtel Nevada Analytical Services Laboratory Procedures Manual. Las Vegas, NV.

Bechtel Nevada. 1995. Nevada Test Site Performance Objective for Certification of Nonradioactive Hazardous Waste, Rev. 0. Las Vegas, NV.

Code of Federal Regulations. 1976. 40 CFR 141.16, Table A, "Average Annual Concentrations Assumed to Produce a Total Body or Organ Dose of 4 mrem/yr." Washington, DC: U.S. Government Printing Office.

Coleman, G.H. 1965. The Radiochemistry of Plutonium, NAS-NS-3058. Washington, DC: National Academy of Sciences.

Grindler, J.E. 1962. The Radiochemistry of Uranium, NAS-NS3050. Washington, DC: National Academy of Science.

Horwitz. 1993. "Separation and Preconcentration of Actinides from Acidic Media by Extraction Chromatography." In Analyticda Chimica Acta. Amsterdam, The Netherlands: Elsevier Publishers, B.V.

Horwitz. 1992. "Separation and Preconcentration of Uranium from Acidic Media by Extraction Chromatography." In Analyticda Chimica Acta. Amsterdam, The Netherlands: Elsevier Publishers, B.V.

RCRA Regulations and Keyword Index. 1998. ISSN 1074-1364. New York, NY: Elsevier Science, Inc.

U.S. Department of Energy. 1992. Environmental Measurements Laboratory Procedures Manual, HASL-300, 27th Edition, Vol. 1. New York, NY. 
U.S. Department of Energy, Nevada Operations Office. 1996. Industrial Sites Quality Assurance Project Plan, Nevada Test Site, Nevada, DOE/NV--372. Las Vegas, NV.

U.S. Environmental Protection Agency. 1980. Prescribed Procedures for Measurements of Radioactivity in Drinking Water, EPA-600/4-79-020. Washington, DC.

U.S. Environmental Protection Agency. 1988a. Contract Laboratory Program Statement of Work for Inorganic Analysis, ILMO 3.0. Washington, DC.

U.S. Environmental Protection Agency. 1988b. Contract Laboratory Program Statement of Work for Organic Analysis, 02/88. Washington, DC.

U.S. Environmental Protection Agency. 1990. Contract Laboratory Program Statement of Work for Organic Analysis, 03/90. Washington, DC.

U.S. Environmental Protection Agency. 1991. Contract Laboratory Program Statement of Work for Organic Analysis, OLMO 1.8. Washington, DC.

U.S. Environmental Protection Agency. 1993. Contract Laboratory Program Statement of Work for Inorganic Analysis, ILMO 3.0. Washington, DC.

U.S. Environmental Protection Agency. 1994a. Contract Laboratory Program Statement of Work for Inorganic Analysis, ILMO 4.0. Washington, DC.

U.S. Environmental Protection Agency. 1994b. Contract Laboratory Program Statement of Work for Organic Analysis, OLMO 3.1. Washington, DC.

U.S. Environmental Protection Agency. 1996. Test Methods for Evaluating Solid Waste, Physical/Chemical Methods, SW-846, $3^{\text {rd }}$ Edition (which includes updates to 1986, 1992, and 1994 revisions), CD-ROM. Washington, DC. 


\section{Appendix D}

\section{NDEP Comments}




\section{NEVADA ENVIRONMENTAL RESTORATION PROJECT}

\section{DOCUMENT REVIEW SHEET}

\begin{tabular}{|c|c|c|c|c|c|}
\hline \multicolumn{4}{|c|}{$\begin{array}{c}\text { 1. Document Title/Number: Corrective Action Investigation Plan for Corrective Action Unit 232: Area } 25 \\
\text { Sewage Lagoons, Nevada Test Site, Nevada, Draft }\end{array}$} & \multicolumn{2}{|l|}{ 2. Document Date: March 1999} \\
\hline \multicolumn{4}{|c|}{ 3. Revision Number: 0} & \multicolumn{2}{|c|}{ 4. Originator/Organization: IT Corporation } \\
\hline \multicolumn{4}{|c|}{ 5. Responsible DOE/NV ERP Project Mgr.: Janet Appenzeller-Wing } & \multicolumn{2}{|l|}{ 6. Date Comments Due: 04/05/99 } \\
\hline \multicolumn{6}{|c|}{ 7. Review Criteria: Full } \\
\hline \multicolumn{4}{|c|}{ 8. Reviewer/Organization/Phone No.: Gregory A. Raab, NDEP, 486-2867 } & \multicolumn{2}{|l|}{ 9. Reviewer's Signature: } \\
\hline $\begin{array}{l}\text { 10. Comment } \\
\text { Number/ } \\
\text { Location }\end{array}$ & 11. Type ${ }^{a}$ & 12. Comment & \multicolumn{2}{|c|}{ 13. Comment Response } & 14. Accept \\
\hline $\begin{array}{l}\text { 1) Section } 1.1 \text {, } \\
\text { Page 1, } \\
\text { Last Sentence } \\
\text { on the Page } \\
\text { continuing to } \\
\text { Page } 4\end{array}$ & M & $\begin{array}{l}\text { This CAIP was developed using the U.S. Environmental } \\
\text { Protection Agency's (EPA) Data Quality Objectives (DQOs) } \\
\text { (EPA, 1994) process to clearly define the goals and set the } \\
\text { DQOs for collecting environmental data to determine data uses, } \\
\text { and to design a data collection program that will satisfy these } \\
\text { goals-and uses. [DQOs do not determine data uses; data users } \\
\text { determine the DQOs for data uses.] }\end{array}$ & \multicolumn{2}{|c|}{ Comments incorporated. } & Accepted \\
\hline $\begin{array}{l}\text { 2) Section 1.2, } \\
\text { Page } 4 \\
1^{\text {st }} \text { Bullet }\end{array}$ & M & - Determine if contamination is present at CAU 232, then: & \multicolumn{2}{|c|}{$\begin{array}{l}\text { Bullet changed to read, "Determine if contamination is } \\
\text { present at CAU } 232 \text { by:". }\end{array}$} & In Part \\
\hline $\begin{array}{l}\text { 3) Section } 1.2 \text {, } \\
\text { Page } 4 \text {, } \\
2^{\text {nd }} \text { Bullet }\end{array}$ & M & $\begin{array}{l}\text { - Determine the nature and extent of COPCs, if any, by: } \\
\text { - tentify Identifying... } \\
\text { - Determine Determining... }\end{array}$ & \multicolumn{2}{|c|}{ Comments incorporated. } & Accepted \\
\hline $\begin{array}{l}\text { 4) Section } 4.0 \text {, } \\
\text { Figure } 4-1\end{array}$ & M & $\begin{array}{l}\text { The only thing lacking in the cross-section is a delineation of the } \\
\text { suspected contamination area. }\end{array}$ & \multicolumn{2}{|c|}{$\begin{array}{l}\text { A line has been added to Figure } 4-1 \text { to delineate that the } \\
\text { extent of suspected contamination is within } 3 \text { vertical feet of } \\
\text { the bottom of the west sewage lagoon. }\end{array}$} & Accepted \\
\hline
\end{tabular}




\section{NEVADA ENVIRONMENTAL RESTORATION PROJECT}

\section{DOCUMENT REVIEW SHEET}

\section{(Page 2 of 2 )}

Document Title/Number: CAIP for CAU 232: Area 25 Sewage Lagoons, NTS, Nevada. Draft

Revision Number:

Reviewer/Organization: G.A. Raab, NDEP

\begin{tabular}{|c|c|c|c|c|}
\hline $\begin{array}{l}\text { 10. Comment } \\
\text { Number/ } \\
\text { Location }\end{array}$ & 11. Type ${ }^{a}$ & 12. Comment & 13. Comment Response & 14. Accept \\
\hline $\begin{array}{c}\text { 5) Section 4.1.2, } \\
1^{\text {st }} \text { Paragraph, } \\
3^{\text {rd }} \text { and } 4^{\text {th }} \\
\text { Sentence; } \\
\text { Appendix A, } \\
\text { Section A.5.0, } \\
2^{\text {nd }} \text { Paragraph, } \\
6^{\text {th }} \text { and } 7^{\text {th }} \\
\text { Sentence }\end{array}$ & $M$ & $\begin{array}{l}\text { Replace the sampling interval } 4 \text { - } 5 \text { feet with approximately } 2 \text { - } 3 \\
\text { feet. If FSLs are elevated at the } 3 \text {-foot interval, then sampling } \\
\text { will continue at approximately } 4-5 \text { feet and } 7 \text { - } 8 \text { feet. Remove } \\
\text { reference to sampling continuing at } 5 \text {-ft intervals until two } \\
\text { consecutive samples have field screening results below FSLs. }\end{array}$ & $\begin{array}{l}\text { Section 4.1.2, first paragraph, third and fourth sentence was } \\
\text { rewritten to read: "Soil sampling and field screening } \\
\text { intervals will be at approximately } 1 \text {-ft and } 3 \text {-ft depths. } \\
\text { Sample collection may be extended to approximately } 5 \text {-ft } \\
\text { and } 8 \text {-ft depths, if field screening results exceed FSLs." } \\
\text { Appendix A, Section A.5.0, second paragraph, sixth and } \\
\text { seventh sentence was revised to read: "Samples will be } \\
\text { collected at approximately } 1 \text {-ft and } 3 \text {-ft depths at each } \\
\text { location. Sample collection may be extended to } \\
\text { approximately 5-ft and 8-ft depths, if field screening results } \\
\text { exceed FSLs." }\end{array}$ & Accepted \\
\hline
\end{tabular}




\section{Distribution}

* Provide copy in distribution of Rev. 0 and subsequent revisions, if applicable.

Copies of the NDEP-approved document will be distributed to others.

Paul J. Liebendorfer

State of Nevada

Bureau of Federal Facilities

Division of Environmental Protection

333 W. Nye Lane, Room 138

Carson City, NV 89706-0851

Mike McKinnon

State of Nevada

Bureau of Federal Facilities

Division of Environmental Protection

555 E. Washington, Suite 4300

Las Vegas, NV 89101

Sabrina Lawrence

Environmental Restoration Division

DOE/Nevada Operations Office

P.O. Box 98518, M/S 505

Las Vegas, NV 89193-8518

Janet Appenzeller-Wing

Environmental Restoration Division

DOE/Nevada Operations Office

P.O. Box 98518, M/S 505

Las Vegas, NV 89193-8518

Sabine Curtis

Environmental Restoration Division

DOE/Nevada Operations Office

P.O. Box 98518, M/S 505

Las Vegas, NV 89193-8518

Jerry Bonn

Bechtel Nevada

P.O. Box 98521, M/S NTS306

Las Vegas, NV 89193-8521
2 (Controlled)*

1 (Controlled)*

1 (Controlled)*

1 (Uncontrolled)*

1 (Uncontrolled)*

1 (Uncontrolled)* 
Steve Nacht

Bechtel Nevada

P.O. Box 98521, M/S NTS306

Las Vegas, NV 89193-8521

Dustin Wilson

SAIC

P.O. Box 93838

Las Vegas, NV 89193

IT Corporation Central Files

P.O. Box 93838

Las Vegas, NV 89193

Linda Linden

SAIC

P.O. Box 93838

Las Vegas, NV 89193

Technical Information Resource Center

DOE/Nevada Operations Office

P.O. Box 98518, M/S 505

Las Vegas, NV 89193-8518

U.S. Department of Energy

Office of Scientific and Technical Information

P.O. Box 62

Oak Ridge, TN 37831

Manager Southern Nevada FFACO

Public Reading Room

P.O. Box 98521, M/S NLV040

Las Vegas, NV 89193-8521

Manager Northern Nevada FFACO

Public Reading Room

c/o Rosa Silver

IT Corporation

P.O. Box 93838

Las Vegas, NV 89193
1 (Uncontrolled)*

1 (Uncontrolled)*

1 (Uncontrolled)*

1 (Controlled)*

1 (Uncontrolled)

1 (Uncontrolled, electronic copy)

1 (Controlled)

1 (Uncontrolled)

1 (Uncontrolled) 
Rosa Silver

IT Corporation

P.O. Box 93838

Las Vegas, NV 89193 